\title{
Spatial and temporal variation of Cladocera in a tropical shallow lake
}

\author{
Wijitra Choedchim ${ }^{1}$, Kay Van Damme ${ }^{2,3}$ and Supiyanit Maiphae ${ }^{4 *}$ \\ 1 Department of Biology, Faculty of Science, Prince of Songkla University, Hat Yai, Songkhla, 90112, Thailand \\ 2 Senckenberg Research Institute and Museum of Nature, Frankfurt a.M., Germany \\ 3 Senckenberg Biodiversity and Climate Research Centre (BiK-F), Frankfurt a.M., Germany \\ ${ }^{4}$ Department of Zoology, Faculty of Science, Kasetsart University, Bangkok, 10900, Thailand
}

Received 3 November 2016; Accepted 22 February 2017

\begin{abstract}
We studied cladoceran species richness, community composition, habitat preference and density in three spatial habitats over 1 year at Thale-Noi, a large shallow tropical lake in southern Thailand. Monthly sampling conducted with activity traps deployed overnight in littoral (Hydrilla and Ceratophyllum beds), open water (Hydrilla beds) and marginal zone (Utricularia beds), revealed that the macrophyte beds support similar cladoceran diversities regardless of the habitat. Total species richness in all studied habitats ranged between 30 and 34 species, supporting up to 22 species in a trapping area of $0.09 \mathrm{~m}^{2}$ at peak times, the majority belonging to the Chydoridae. In total, 40 species were recorded over the year, half of which were chydorids. Mixed cladoceran densities reached maxima of 160333 ind $\mathrm{m}^{-2}$ for a single habitat at a given moment. The dominant species included Chydoridae (Anthalona, Kurzia, Dunhevedia and Ephemeroporus), Daphniidae (Ceriodaphnia), Macrothricidae (Macrothrix) and Ctenopoda (Latonopsis). Monthly variation in species richness was most obvious in the littoral zone, whereas monthly variation in densities occurred at all sites. Community composition and habitat preference were mainly structured by depth and $\mathrm{pH}$, resulting in different assemblages per habitat, but with uniform communities in the littoral (Hydrilla and Ceratophyllum) beds in a single area. This study presents the first ecological survey of Cladocera using activity traps in a shallow tropical lake.
\end{abstract}

Key words: Cladocera / diversity / community / habitat preference / tropical lakes

\section{Introduction}

Cladocera (Crustacea: Branchiopoda) are one of the major groups of freshwater zooplankton and make up a vital part of aquatic food webs worldwide by linking the lower (phytoplankton, bacteria, fungi) and higher trophic levels (fish, macro-invertebrates) (Dodson and Frey, 1991). The non-pelagic Cladocera, of which the majority consists of the speciose family Chydoridae, thrive in littoral areas of freshwater habitats and in shallow freshwater lakes, where aquatic macrophytes dominate (Whiteside and Harmsworth, 1967; Smirnov, 1974). The littoral provides shelter against predators for pelagic as well as non-pelagic species. It also provides food, as phytophilic cladocerans feed mainly on epiphyton and Aufwuchs (Fryer, 1968; Stansfield et al., 1997; Geraldes and Boavida, 2004). Often, the littoral is understood as a single habitat.

\footnotetext{
*Corresponding author: supiyanit.maku.ac.th
}

It is clear that under this general term, high diversity in micro-habitats is present among small aquatic invertebrates such as cladocerans (e.g., Whiteside et al., 1978).

Many cladocerans are thought to prefer particular plant species (Hann, 1995) or substrates (Whiteside et al., 1978). However, most phytophilic cladocerans are represented by both generalist as well as highly-specialized lineages, from general grazers to specialized benthic species (Fryer, 1968). Community composition of non-pelagic cladocerans is strongly influenced by physical and chemical factors such as depth, $\mathrm{pH}$, temperature, conductivity and total organic carbon (TOC). Depth is an important factor determining the distribution of benthic chydorids in a lake, even within the littoral zone (Adamczuk, 2014). Different patterns of distribution can be observed along a depth gradient, forced by UV exposure, thermal properties, food resources and the predators associated with these varying depths (Nevalainen, 2012). The community structure of chydorids is affected by $\mathrm{pH}$ (Sa-ardrit, 2002; 
de Eyto et al., 2003; Nachai, 2006; Belyaeva and Deneke, 2007; Adamczuk, 2014) to such an extent that it influences their distribution on a geographical scale (de Eyto et al., 2003). The segregation of some chydorids in lakes may also be related to temperature and conductivity (Sa-ardrit, 2002; Nevalainen, 2012). Finally, TOC influences chydorids indirectly, with correlations between high TOC concentrations and elevated densities of some Chydoridae, suggesting that these species could prefer areas of higher productivity. They can also utilize organic matter suspended in the water (Adamczuk, 2014). Moreover, the density of zooplankton communities fluctuates in relation to the period (season), even in the tropics (Guevara et al., 2009).

Despite their ecological importance, not many ecological studies aimed at Cladocera in tropical waters have been performed, particularly on littoral-benthic species. Even in temperate waters, relatively little is known about the ecological preferences of phytophilic cladocerans (e.g.,Whiteside et al., 1978). Therefore, the effects of habitat types on the abundance of non-pelagic cladocerans remain unclear. Most studies focusing on the association between species and their microhabitat use different sampling methods such as the Downing box, Ekman grab, or plexiglass tubes (e.g., Hann, 1995). Cladocera can escape from such traps while being collected, which negatively influences the accuracy of the result and reproducibility of the methods. Thus far, all detailed studies on habitat preference in non-pelagic cladocerans have been limited to temperate lakes (Whiteside and Harmsworth, 1967; Whiteside et al., 1978; Barton and Carter, 1981; Di Fonzo and Campbell, 1988; Paterson, 1993; Hann, 1995; Tremel et al., 2000; Walseng et al., 2008). This leaves the tropical freshwater ecosystems virtually unexplored with regard to non-pelagic cladoceran ecology, despite the fact that their diversity in tropical waters is high (Fernando, 1980) and that their importance as food for fish and invertebrates (in turn, for birds and amphibians) cannot be underestimated. It is surprising that so little is known about cladoceran communities and the diversity in tropical wetlands. Extending knowledge about the diversity and ecology of tropical cladocerans is important for tropical community ecology as well as for understanding the roles these important primary consumers play in tropical waters and in the biodiversity conservation of freshwater ecosystems (Groom et al., 2006).

To investigate whether tropical cladoceran communities differ between micro-habitats as defined by dominant submerged macrophytes, we focused on Thale-Noi Lake, a large, shallow, tropical wetland in Southern Thailand. The Cladocera fauna and diversity of Thailand is among the best understood in South East Asia, thanks to intense efforts in taxonomy (e.g., Maiphae, 2005; Korovchinsky, 2013; Van Damme et al., 2013), which now form a firm basis for tropical cladoceran ecology. We paid close attention to ensuring an up-to-date, rigorous taxonomy in this study. Thale-Noi Lake is one of the best studied wetlands in Thailand, with a large diversity in macrophyte stands and zooplankton fauna (of which the taxonomy was recently updated) where basic Cladocera ecology studies have been conducted (Inpang, 2008; Pholpunthin et al., 2009). This study aimed to investigate cladoceran diversity, density and community composition over a year in different habitats in Thale-Noi Lake, representative of the major zones in this shallow tropical lake, using a quantitative sampling method.

\section{Study site}

Thale-Noi Lake is a shallow tropical freshwater lake situated in Phatthalung Province, Southern Thailand, making up the northern part of the large Songkhla Lake system. It is located between latitude $7^{\circ} 45^{\prime} 44^{\prime \prime} \mathrm{N}$ to $7^{\circ} 48^{\prime} 26^{\prime \prime} \mathrm{N}$ and longitude $100^{\circ} 7^{\prime} 31^{\prime \prime} \mathrm{E}$ to $100^{\circ} 11^{\prime} 12^{\prime \prime} \mathrm{E}$ (Leingpornpan and Leingpornpan, 2005). The runoff from the Bunthad Mountain slopes forms the principle inflow to the lake and the outflow runs via the Klong Nang Riam, Klong Yuan and Klong Ban Glang canals into Thale Lung, Lake Songkhla. Thale-Noi Lake itself is usually fresh, with salinity ranging between 0.1 and 0.8 ppt. However, the lake can occasionally become brackish in some areas due to the saltwater influx from Songkhla Lake during the dry season (Inpang, 2008). The salinity in Songkhla Lake fluctuates with precipitation (Angsupanich and Rakkheaw, 1997; Angsupanich et al., 2005; Ruensirikul et al., 2007): in the rainy season, values $(0-1.5 \mathrm{ppt})$ are higher than in the dry season $(0-0.7 \mathrm{ppt})$. Thale-Noi Lake is a shallow lake, with an average depth of $1.2 \mathrm{~m}$ (Pholpunthin et al., 2009) ranging between 0.7 and $2.3 \mathrm{~m}$. It is slightly acidic because of accumulation of peat as well as acidic water influx from peat swamp forests near the northern shore (Inpang, 2008).

Because Thale-Noi is shallow, the bottom is largely covered in macrophytes. The macrophytes are classified into four categories; 38 species of marginal plants, eight species of emerged plants, eight species of floating plants and six species of submerged plant (Leingpornpan and Leingpornpan, 2005). The most common macrophytes in Thale-Noi are Cyperus pilosus Vahl., Hanguana malayana (Jack) Merr., Salvinia cucullata Roxb. ex Bory, Eleocharis ochrostachys Steud., Nymphoides indicum (L.) Kuntze, Nymphaea lotus L., Nelumbo nucifera Gaertn., Eicchornia crassipes (C.Mart.) Solm, Hydrilla verticillata (L.f.) Royle, Utricularia spp. and Hygroryza aristata (Retz.) Nees ex Wight \& Arn. (Leingpornpan and Leingpornpan, 2005).

The wetland is characterized by high structural complexity, harboring high biodiversity (Artharamas, 1984). The lake is one of the largest conserved freshwater wetlands in Thailand, aimed at preserving the sustainable ecology of the area (Aiumnau et al., 2000).

\section{Methods}

Samples were collected monthly in Thale-Noi over 1 year, from May 2014 to May 2015. We selected three 


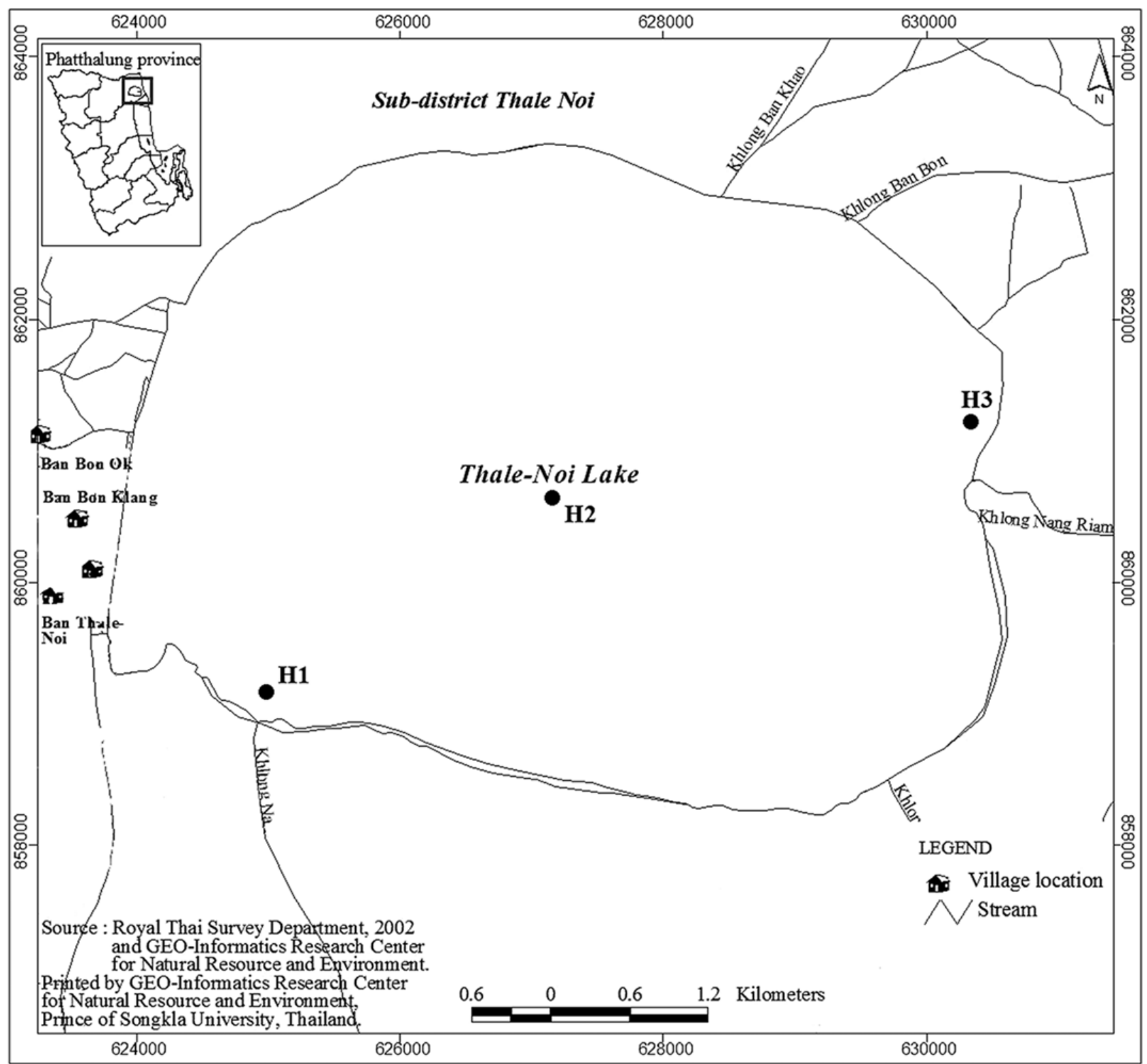

Fig. 1. Study area and selected habitats at Thale-Noi Lake, Southern Thailand. H1 = habitat $1, \mathrm{H} 2=$ habitat 2 , H3 = habitat 3 .

different habitat types, representing the dominant vegetation communities of submerged macrophytes in the lake, all with fine dissected leaves (Fig. 1). All habitats were on similar substrates (mud/detritus). Animals were collected by a quantitative sampling method, using arrays of funnel traps (Fig. 2) in different habitats.

Habitat 1 (H1) is situated closest to the mouth of the Yuan River in the South West of Thale-Noi Lake, an area with high diversity and high density of macrophytes. This habitat corresponds to the littoral in Inpang (2008), next to a residential area with human settlements.

Habitat $2(\mathrm{H} 2)$ is part of the large open water area in the centre of Thale-Noi Lake, characterized by low macrophyte diversity that cover the lake bottom and the bottom is covered with a thick detritus layer (Inpang, 2008). We labeled this as the "open water zone", the equivalent to Thale-Noi's "pelagic".
Habitat 3 (H3) is located near the Nang Riam river in the North East of the wetland, where the water chemistry depends on the sea level, with elevated salinity and conductivity. This area is influenced by a low $\mathrm{pH}$ from the peat swamp zone that is situated in the north of the lake. This habitat is highly diverse in macrophytes and was named in previous studies as the "small inlet zone" (Inpang, 2008). The main differences between the three habitat types are listed in Table 1.

We used a quantitative sampling method (activity traps), a successful approach to estimate cladoceran density per lake volume and area, modified from the funnel trap model of Örnólfsdóttir and Einarsson (2004), of which the design is based on the principle of the "pattern sampler" used by Whiteside and Williams (1975) for cladocerans. The trap is easily deployed and the frame creates little disturbance when lowered into the water 

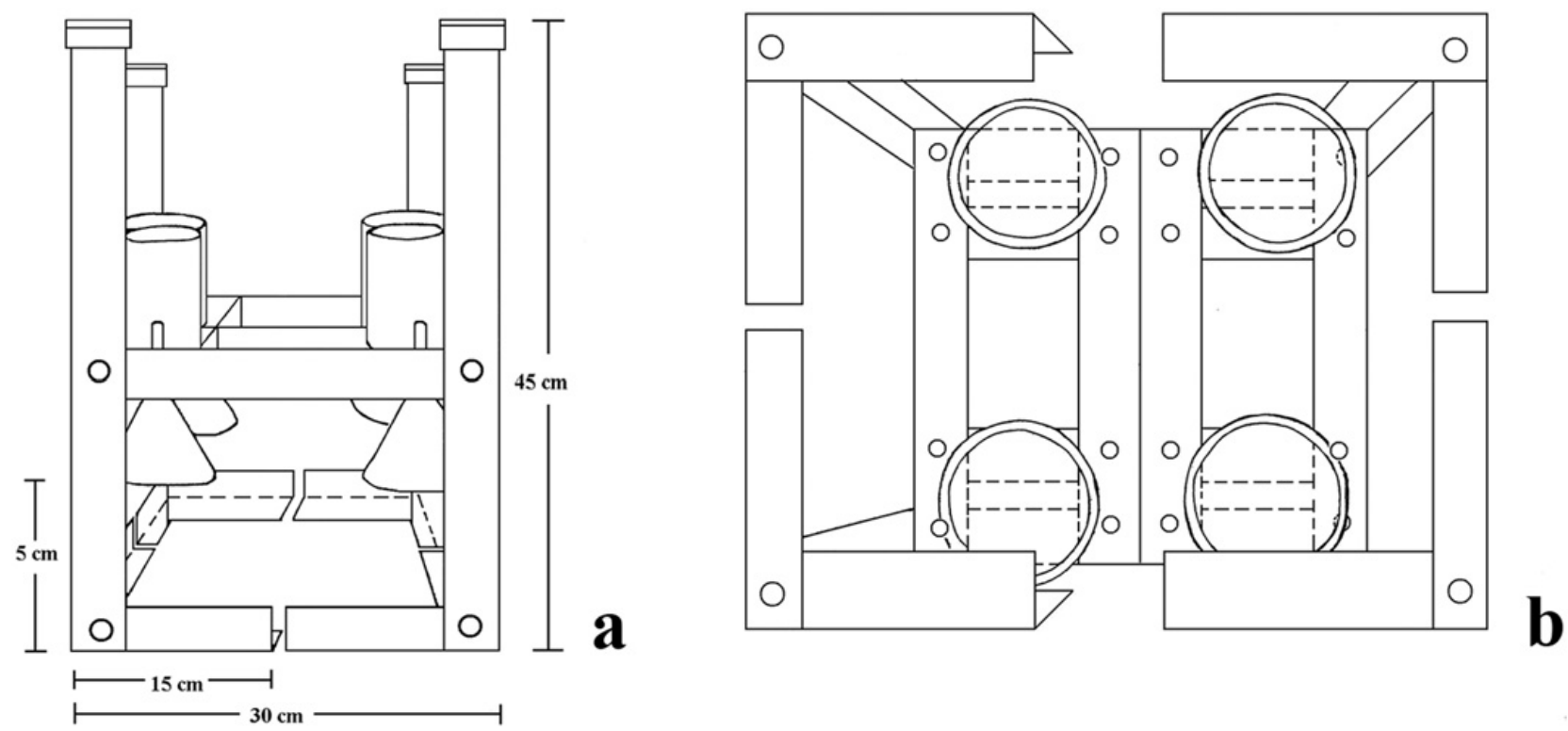

Fig. 2. The funnel trap $a=$ lateral view, $b=$ top view.

column from a boat. Each trap consists of a plastic recipient with a funnel mounted on the lid, suspended upside down and $3 \mathrm{~cm}$ above the sediment. The Cladocera venture through the funnel and are trapped in the bottle. Örnólfsdóttir and Einarsson (2004) carried out experiments to test the efficiency of these traps at different distances between the funnel mouth and the sediment surface. Besides being efficient traps, this method allows quantitative estimations by converting the number of individuals per $\mathrm{m}^{2}$ from the total surface area of the funnels. Our traps (Fig. 2) consist each of an array of four plastic bottles, each with a funnel attached to the lid (funnel diameter $10 \mathrm{~cm}$, height $12 \mathrm{~cm}$, total area of four funnel openings $0.03 \mathrm{~m}^{2}$, bottle volume $370 \mathrm{~mL}$ ). The bottle-funnel sets are mounted on a metal frame with grid squares and there are four legs to fix the frame. The distance between the funnel opening and the sediment is about $5 \mathrm{~cm}$. During each sampling, three individual traps ( $=3 \times 4$ bottles) were deployed per selected macrophyte patch in each habitat (three replications in H1.HY, H1.Ce, $\mathrm{H} 2$ and $\mathrm{H} 3$ ). A total of 48 samples were collected every month and in total 624 samples were collected for the whole field work period. Each trap was placed horizontally over the lake sediment (and the macrophytes) and left overnight (12 h), allowing the cladocerans to enter by swimming during upwards vertical migration.

Samples were fixed in the field with $95 \%$ alcohol, transported to the laboratory and counted under an Olympus SZ- 40 stereomicroscope. All the specimens of all species found in each sample were counted. The morphological details were examined using an Olympus $\mathrm{CH}-2$ compound microscope. The cladocerans were identified to species level following standard keys and works such as Smirnov (1974, 1996), Idris (1983), recent revisions such as Dumont and Silva-Briano (2000), Kotov (2003), Kotov et al. (2005) and Korovchinsky (2013), and regional updates such as Maiphae (2005), Van Damme et al. (2010, 2011, 2013), Sinev (2012), Sinev and Kotov (2012), and Van Damme and Maiphae (2013). Close attention was paid to the correct identification of each specimen, including comparison with closely related species that have hitherto been ignored (e.g., Anthalona species). The calculation of the number of adult (male and female) individuals. $\mathrm{m}^{-2}$ (juveniles were not included) was done using the following (based on Tremel et al., 2000):

The surface area of each funnel $=(22 / 7) \times 0.05^{2} \mathrm{~m}^{2}$ $=0.007857 \mathrm{~m}^{2}$

Surface area four funnels $=0.0078 \times 4=0.03 \mathrm{~m}^{2}$

Density/trap; individuals. $\mathrm{m}^{-2}=$ individuals $\times 0.03^{-1}$

Eight environmental parameters (depth, $\mathrm{pH}$, salinity, water temperature, conductivity, transparency, dissolved oxygen and chlorophyll a) were measured for each macrophyte patch. Per sampling, depth was measured by a rope with weighted pendulum, $\mathrm{pH}$ was measured using a YSI multimeter 60 model 60/10 FT. Salinity, water temperature and conductivity were measured using a YSI multimeter 30 model 30/10 FT, transparency was measured using a Secchi disc, dissolved oxygen was analyzed following the Azide Modification/Iodometric Method (titration with standard solution: sodium thiosulphate with starch indicator solution) and chlorophyll $a$ using the spectrophotometric method (Spectrophotometer, Thermo Electron Corporation, Spectronic 20 + ) (APHA, AWWA, and WEF, 1998).

\section{Statistical analyses}

1.The differences of cladoceran species richness, total cladoceran density and the density per species among habitats were analyzed using a nonparametric 


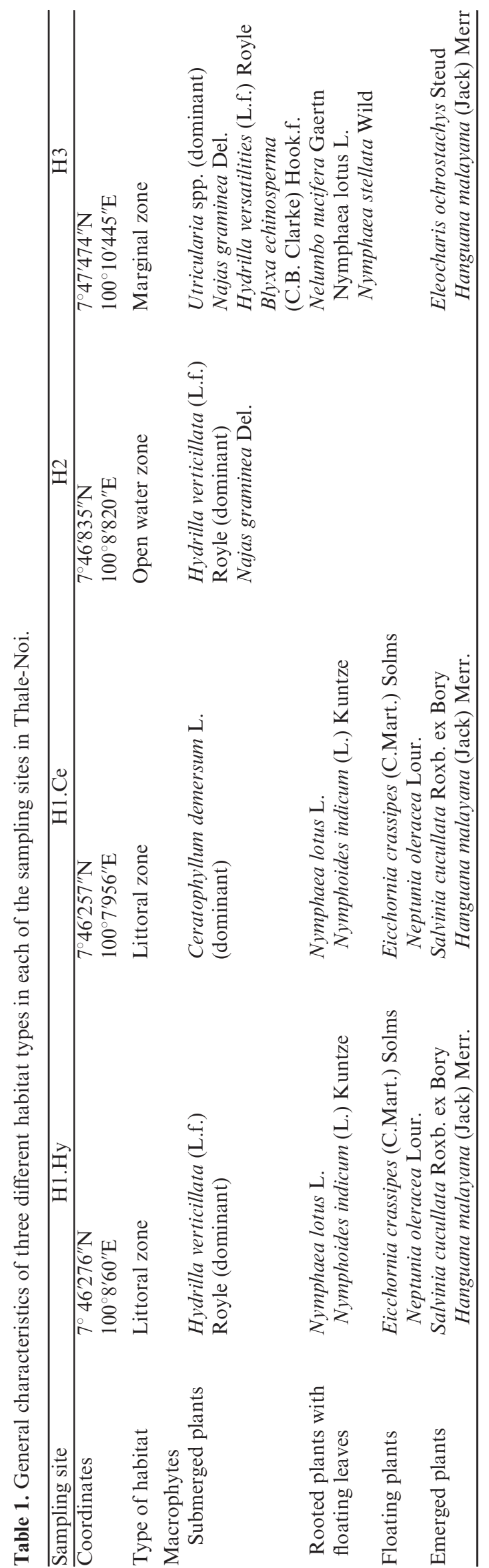

Kruskal-Wallis Test ( $\mathrm{R}$ program, version 3.2). Data from all samples per each trap were included for the analysis (H1: $n=78, \mathrm{H} 2$ and $\mathrm{H} 3: n=39)$.

2.We used one-way ANOVA to test the differences of total species richness and used nonparametric analysis (Kruskal-Wallis) to test the differences of total density in each macrophyte patch between the seasons ( $\mathrm{R}$ program, version 3.2); the sum of all samples in each trap was used in the analyses (all macrophyte patches: $n=39$; dry season: $n=24$ and rainy season: $n=15$ ).

3.The differences of cladoceran density per species between seasons were analyzed using a nonparametric method (Kruskal-Wallis) ( $\mathrm{R}$ program, version 3.2) (each species, dry season: $n=96$ and rainy season: $n=60)$.

4.We used one-way ANOVA and a nonparametric test (Kruskal-Wallis) to test the differences of the environmental factors between the habitats (each factor; H1: $n=26, \mathrm{H} 2$ and $\mathrm{H} 3: n=13$ ) and tested environmental factors in each macrophyte patch between seasons (each factor in each macrophyte patch; dry: $n=8$ and rainy: $n=5$ ). The raw data of environmental factors were $\log 10(x+1)$ transformed to increase normality for the subsequent analyses. For data that fulfilled the normality assumption, we used one-way ANOVA (the post hoc analysis was run using Tukey's test) and data that did not fulfill the normality assumption were tested using a nonparametric Kruskal-Wallis Test (the significant different factors were tested with the Mann-Whitney $U$ test to compare means between groups) in $\mathrm{R}$ (3.2).

5.To explore the similarities in species composition, we used Cluster analysis with PCORD (5.0).

6.The relationship between species and environmental factors was analyzed using canonical correspondence analysis (CCA) in PCORD (5.0). Only factors that significantly differed among habitats were included in the CCA analysis. Species with a relative density lower than $0.1 \%$ were excluded. Monte-Carlo permutation tests were performed (1000 runs) to test the statistical strength of eigenvalues of the ordination axes and of the species-environment correlations.

\section{Results}

\section{Environmental conditions}

Only two environmental factors, $\mathrm{pH}$ and depth, showed a significant difference between $\mathrm{H} 2$ and $\mathrm{H} 3$ and only depth showed significant difference between $\mathrm{H} 1$ and H3 (depth; $P=0.001, F=8.242$, d.f. $=2, \quad \mathrm{pH}$; $P=0.007, x^{2}=9.934$, d.f. $\left.=2\right)$. The highest depth was found in $\mathrm{H} 1(2.1 \mathrm{~m})$ and the lowest in $\mathrm{H} 3(0.63 \mathrm{~m})$; $\mathrm{pH}$ was the highest in $\mathrm{H} 2$ (10.17), while the lowest was recorded in $\mathrm{H} 3$ (3.54). The widest salinity range appeared in $\mathrm{H} 3$ $(0-1.5 \mathrm{ppt})$, whereas the lowest was recorded in $\mathrm{H} 2$ $(0-0.7 \mathrm{ppt})$. Water temperature was similar in all habitats. The highest was found in $\mathrm{H} 3$ in June $\left(34.8^{\circ} \mathrm{C}\right)$, 

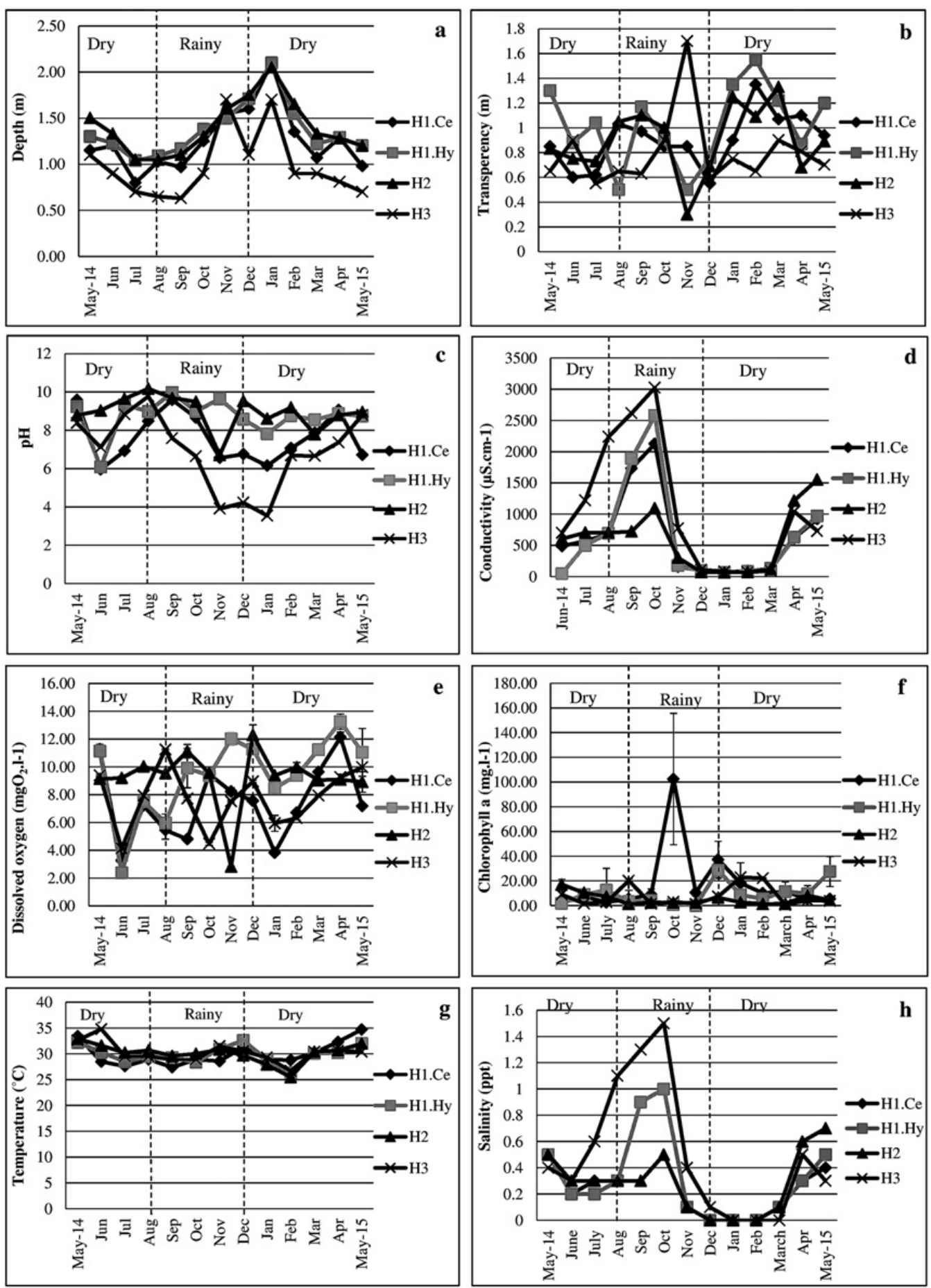

Fig. 3. Monthly fluctuation of each environmental parameters measured in Thale-Noi Lake between May 2014-May 2015, a; depth, b; transparency, c; pH, d; conductivity, e; dissolved oxygen, f; chlorophyll $a$, g; temperature, h; salinity * chlorophyll a and dissolved oxygen used mean values.

while the lowest was found in $\mathrm{H} 2\left(25.5^{\circ} \mathrm{C}\right)$. The highest conductivity occurred in $\mathrm{H} 3$ (3026 $\left.\mu \mathrm{S} . \mathrm{cm}^{-1}\right)$, with the lowest in H1.Hy $\left(51.5 \mu \mathrm{S} . \mathrm{cm}^{-1}\right)$. The highest transparency appeared in $\mathrm{H} 3(1.7 \mathrm{~m})$, while the lowest appeared in $\mathrm{H} 2(0.3 \mathrm{~m})$. H1.Hy showed the highest dissolved oxygen $\left(13.26 \mathrm{mgO}_{2} \cdot \mathrm{L}^{-1}\right)$, with the lowest found in $\mathrm{H} 2 \quad\left(2.39 \mathrm{mgO}_{2} \cdot \mathrm{L}^{-1}\right)$ (Fig. 3). In addition, the environmental factors were not significantly different between two seasons, except for transparency. We found that the transparency in H1.Hy showed a significant difference between the dry and rainy seasons $(P<0.05$, $F=7.909$, d.f. $=1)$. In the dry season $(1.18 \pm 0.24)$, transparency was higher than in the rainy season $(0.77 \pm 0.28)$. 
Table 2. Difference of cladoceran density (mean $\pm \mathrm{SD}$ ) for each habitat (ind. $\mathrm{m}^{-2}$ ) and $P$-value from the nonparametric (Kruskal-Wallis) test.

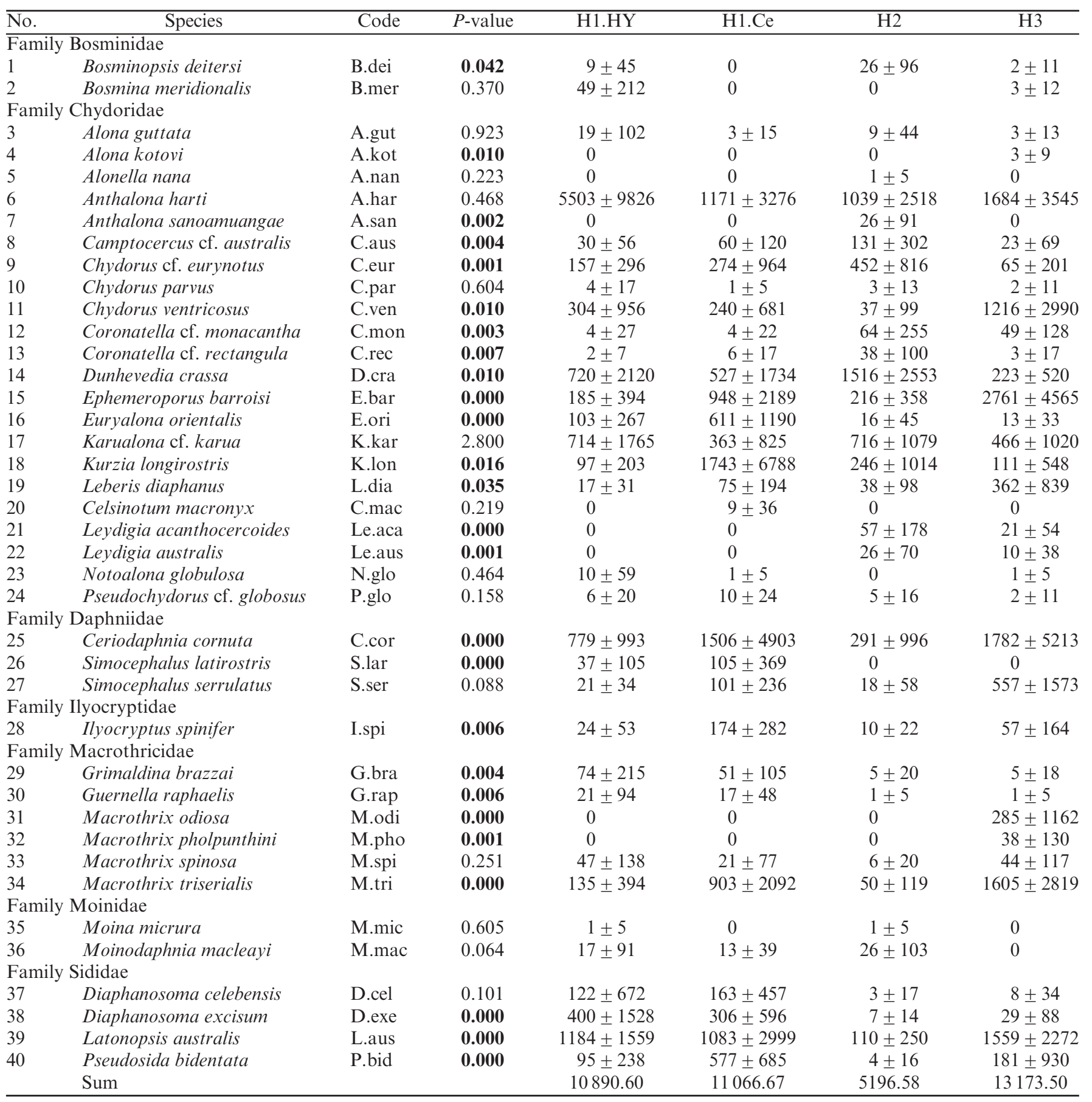

\section{Species richness}

A total of seven families, 28 genera and 40 species of Cladocera were retrieved from the sampling area over the period of study (Table 2). The best represented families were the Chydoridae (22 species) and Macrothricidae (6 species), followed by the Sididae (4 species) and Daphniidae (3 species). Two species are new records for Thailand, Alona kotovi Sinev, 2012 (sibling species of
Alona quadrangularis) and Diaphanosoma celebensis Stingelin, 1900.

The species richness of Cladocera per habitat is similar (year total; 30-34 species). The highest species richness was found in H3 (34 species), followed by H2 (33 species), $\mathrm{H} 1$ in the Hydrilla bed (H1.Hy; 32 species) and the lowest in the Ceratophyllum beds (H1.Ce; 30 species). Species richness per trap and per sampling ranged between 0 and 22 species. Variance among the three traps in each 

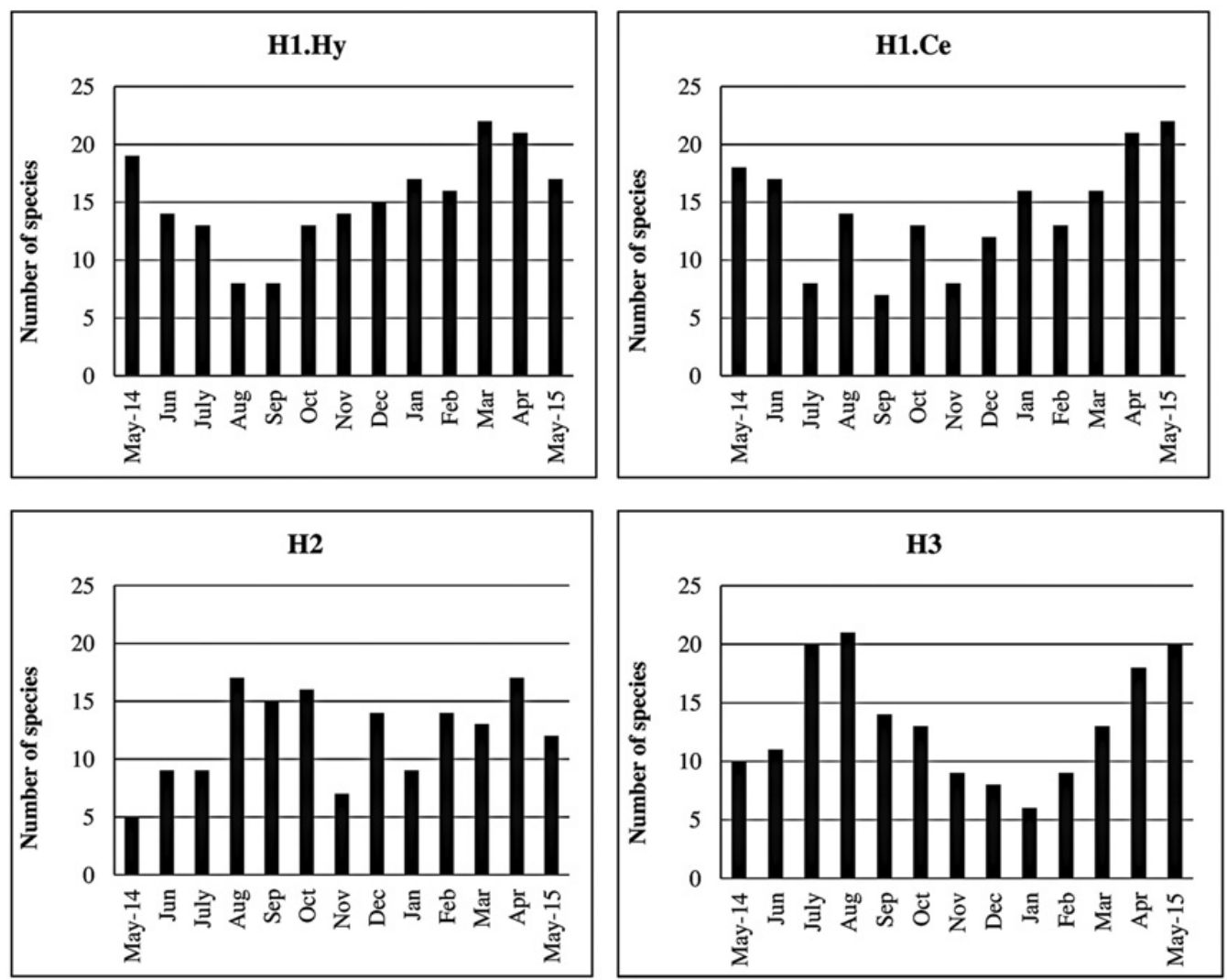

Fig. 4. Total Cladocera species richness as recorded from the activity traps $(n=3)$ in Thale-Noi Lake, Southern Thailand, May 2014-2015.

macrophyte patch ranged between 0 and 7 species, but about $90 \%$ of the macrophyte patch showed lower variance of between 1 and 4 species. There were 26 species that occurred in all habitats, with six species found in only one habitat (A. kotovi, Alonella nana, Anthalona sanoamuangae, Celsinotum macronyx, Macrothrix odiosa and Macrothrix pholpunthini). The species richness did not differ significantly among habitats in the same period $\left(P=0.051, x^{2}=\right.$ 5.937 d.f. $=2$ ), while they differed significantly between seasons in H1.Hy $(P=0.005, F=9.025$ d.f. $=1)$, in H1.Ce $(P=0.000, F=15.532$ d.f. $=1)$ and in $\mathrm{H} 2(P=0.001$, $F=15.016$ d.f. $=1)$. Species richness in H1.Hy and H1.Ce was higher during the dry season than during the rainy season, while the opposite appeared in $\mathrm{H} 2$ (species richness average in dry season; $\mathrm{H} 1 . \mathrm{Hy}=11.96 \pm 4.80, \mathrm{H} 1 . \mathrm{Ce}=$ $12.54 \pm 4.90$ and $\mathrm{H} 2=5.40 \pm 3.44$, species richness average in rainy season; $\mathrm{H} 1 . \mathrm{Hy}=8.53 \pm 2.26, \mathrm{H} 1 . \mathrm{Ce}=7.67 \pm 2.82$ and $\mathrm{H} 2=10.13 \pm 3.25$ ).

Species richness in H1.Hy was the highest in March (22 species) and the lowest in August and September (eight species). This was similar in H1.Ce, where species richness was the highest in May (22 species) and the lowest in September (seven species). Species richness in $\mathrm{H} 2$ was the highest in August and April (17 species) and the lowest in May (five species; but not as low in the consecutive year, with 12 species), while species richness in $\mathrm{H} 3$ was the highest in August (21 species) and the lowest in January (six species) (Fig. 4). Three species were found only in the dry season (Bosminopsis deitersi, C. macronyx, M. odiosa and $M$. pholpunthini) and three species were found only in the rainy season (A. kotovi, Alonella nana and $A$. sanoamuangae), of which two species were encountered only once (A. kotovi and A. nana) (August), in low numbers.

\section{Density}

The highest cladoceran density over 1 year was found in H3, followed by H1.Ce and comparable with H1.Hy, and the lowest in $\mathrm{H} 2$ (Table 2). The total number of cladocerans per trap per sampling ranged between 0 and 1482 individuals $(302.46 \pm 302.31)$. The variance among three traps for each macrophyte patch ranged between 1 and 544 individuals, with about $86 \%$ of each macrophyte patch showing a variance of less than 250 individuals. The total density differed significantly between $\mathrm{H} 1$ and $\mathrm{H} 2, \mathrm{H} 2$ versus $\mathrm{H} 3\left(P=0.002, x^{2}=12.522\right.$, d.f. $\left.=2\right)$, while density between $\mathrm{H} 1$ and $\mathrm{H} 3$ did not differ significantly.

In total 26 species of cladocerans showed significant habitat differences. Four species were found restricted to only one habitat: A. sanoamuangae, A. kotovi, M. odiosa and M. pholpunthini. Euryalona orientalis, Kurzia longirostris, Simocephalus latirostris, Ilyocryptus spinifer and Pseudosida bidentata showed the highest density in H1.Ce. Grimaldina brazzai, Guernella raphaelis and Diaphanosoma 

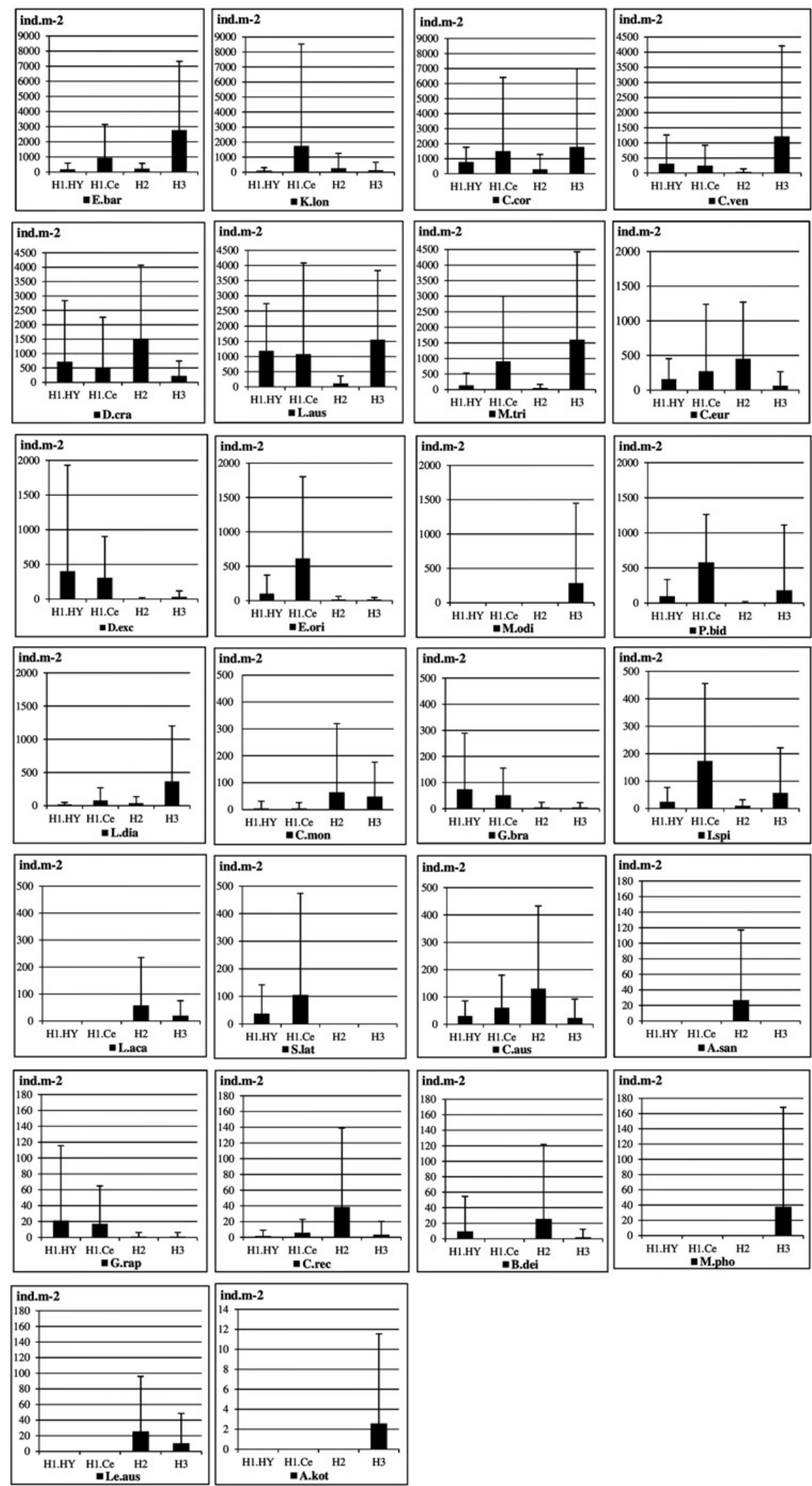

Fig. 5. Mean density $( \pm$ SD) of cladoceran found in each macrophyte patch between May 2014-2015. Species code; see Table 2. 
excisum showed the highest density in H1.Hy. B. deitersi, Camptocercus cf. australis, Chydorus cf. eurynotus, Coronatella cf. monacantha, Coronatella cf. rectangula, Dunhevedia crassa, Leydigia australis and Leydigia acanthocercoides were dominant in $\mathrm{H} 2$, while Chydorus ventricosus, Ephemeroporus barroisi, Leberis diaphanus, Ceriodaphnia cornuta, Macrothrix triserialis and Latonopsis australis were mainly abundant in H3 (see Fig. 5; Table 2).

Monthly densities varied the most in $\mathrm{H} 3$ and H1.Ce, with the highest numbers in April $\left(33822 \pm 3843\right.$ ind. $\left.\mathrm{m}^{-2}\right)$ and May $\left(35444 \pm 15711\right.$ ind. $\left.^{-2}\right)$ and the lowest in January $\left(400 \pm 88\right.$ ind. $\left.\mathrm{m}^{-2}\right)$ and September $\left(844 \pm 51\right.$ ind $\left.\mathrm{m}^{-2}\right)$. The highest densities in H1.Hy were found in April (27589 \pm 11933 ind. $\left.\mathrm{m}^{-2}\right)$ and the lowest in August $\left(1789 \pm 1764\right.$ ind. $\left.\mathrm{m}^{-2}\right)$. In H2, the highest density was found in October $\left(18656 \pm 5180\right.$ ind. $\left.\mathrm{m}^{-2}\right)$ and the lowest in May $\left(167 \pm 145\right.$ ind. $\left.\mathrm{m}^{-2}\right)$. Total cladoceran density over the year in each habitat peaked during the mid-rainy season (September and October) and in the mid-summer season (February and April), with the lowest overall density occurring in June, November and January (Fig. 6). The total cladoceran density in each macrophyte patch was not significantly different between seasons $(P ; \mathrm{H} 1 . \mathrm{Hy}=0.840, \mathrm{H} 1 . \mathrm{Ce}=0.863, \mathrm{H} 2=0.094$ and $\mathrm{H} 3=0.862$ ). However, when we compared the density for each species between the dry and rainy seasons, 15 species showed significant differences, including a few rare species. A. kotovi $(P=0.027)$ and $A$. sanoamuangae $(P=0.011)$ were found only in the rainy season, $M$. pholpunthini $(P=0.033)$ and $M$. odiosa $(P=0.015)$ were found only in the dry season. Camptocercus cf. australis $(P=0.011)$, Chydorus $\mathrm{cf}$. eurynotus $(P=0.000)$, C. ventricosus $(P=0.000)$, Dunhevedia crassa $(P=0.033)$, E. barroisi $(P=0.000)$, Pseudochydorus cf. globosus $(P=0.005)$, Simocephalus serrulatus $(P=0.006)$ and Macrothrix spinosa $(P=0.014)$ were found in the dry season, with higher densities than in the rainy season, whereas Leydigia acanthoceroides $(P=0.000)$, Guernella raphaelis $(P=0.008)$ and $D$. celebensis $(P=0.034)$, were more abundant in the rainy season than in the dry season.

Males of three cladoceran species were noted, although in low densities, and recorded only five times over the year. Males of Moinodaphnia macleayi were found in $\mathrm{H} 1$ and $\mathrm{H} 3$ in December $\left(189 \pm 327\right.$ and $11 \pm 19$ ind. $\mathrm{m}^{-2}$, respectively), while males of Anthalona harti were found in $\mathrm{H} 2$ and $\mathrm{H} 3$ in August $\left(33 \pm 58\right.$ and $89 \pm 102$ ind. ${ }^{-2}$, respectively). Males of $D$. celebensis were found in $\mathrm{H} 1$ in April $\left(11 \pm 19\right.$ ind. $\left.\mathrm{m}^{-2}\right)$, November $\left(11 \pm 19\right.$ ind. $\left.\mathrm{m}^{-2}\right)$ and December $\left(33 \pm 33\right.$ ind. $\left.\mathrm{m}^{-2}\right)$. Shedded resting eggs of different species were found in the samples in January, February, June, August, September and November, but were not counted.

\section{Relative differences in abundances between taxa}

A. harti had the highest relative abundance of all cladocerans in H1.Hy (50\%), followed by the L. australis group $(11 \%)$ and C. cornuta $(8 \%)$; the lowest was Moina micura $(0.007 \%)$ (Fig. $7(\mathrm{a}))$. The highest relative abundance in H1.Ce was made up of $K$. longirostris $(16 \%)$, followed by $C$. cornuta $(14 \%)$ and $A$. harti $(11 \%)$. The lowest in abundance was Chydorus parvus $(0.008 \%)$. In $\mathrm{H} 2, D$. crassa showed the highest relative abundance (29\%), followed by A. harti (20\%) and Karualona cf. karua $(14 \%)$. The lowest were $A$. nana and $G$. raphaelis $(0.016 \%)$. E. barroisi showed the highest relative abundance in $\mathrm{H} 3(21 \%)$, followed by $C$. cornuta $(14 \%)$ and A. harti (13\%); the rarest was Notoalona globulosa $(0.006 \%)$.

A. harti was found in all macrophyte patches, but showed distinct dominance in H1.Hy, where the relative abundance was high (50\%). The abundance was less than $25 \%$ in the other sites.

\section{Community shifts in dominance}

A. harti, L. australis group, C. cornuta, D. crassa and Karualona cf. karua were dominant species in H1.Hy (see Table 2). A. harti showed the greatest density in September. L. australis was the most abundant in October. D. crassa and Karualona cf. karua were present at all times, but had maximum numbers in February. C. cornuta was found all year round, but was the most abundant in November (Fig. 8(a)).

Dominance in H1.Ce differed, with $K$. longirostris being the most abundant species, followed by $C$. cornuta, A. harti, L. australis group and E. barroisi (Table 2). $C$. cornuta and $A$. harti showed a similar fluctuation in densities; they peaked initially in October and again in April. L. australis was most abundant in October, as in H1.Hy and E. barroisi had the greatest density in March, while other species appeared in low densities (Fig. 8(b)).

In $\mathrm{H} 2, D$. crassa was the dominant species, followed by $A$. harti, Karualona cf. karua, Chydorus cf. eurynotus and C. cornuta (Table 2). D. crassa and Karualona cf. karua showed similar patterns, with maximum density in October and minimum in November. $A$. harti was the most abundant in April. Chydorus cf. eurynotus had its greatest density in August, March and April. C. cornuta was very low in density and peaked only in March when $A$. harti was not found and D. crassa and Karualona cf. karua were very rare (Fig. 8(c)).

E. barroisi, C. cornuta, A. harti, Macrothrix triseralis and $L$. australis group were the most abundant cladoceran species in H3 (Table 2). E. barroisi was the species with the highest density, with their maximum occurring in April. C. cornuta showed a low density and peaked only in September. A. harti was found throughout the year, but showed a density peak in September and April, while $M$. triseralis had a maximum in February (Fig. 8(d)).

In addition, we found that smaller-sized species (the majority of the Chydoridae) seemed to appear in high density when larger-size species (Macrothricidae, 


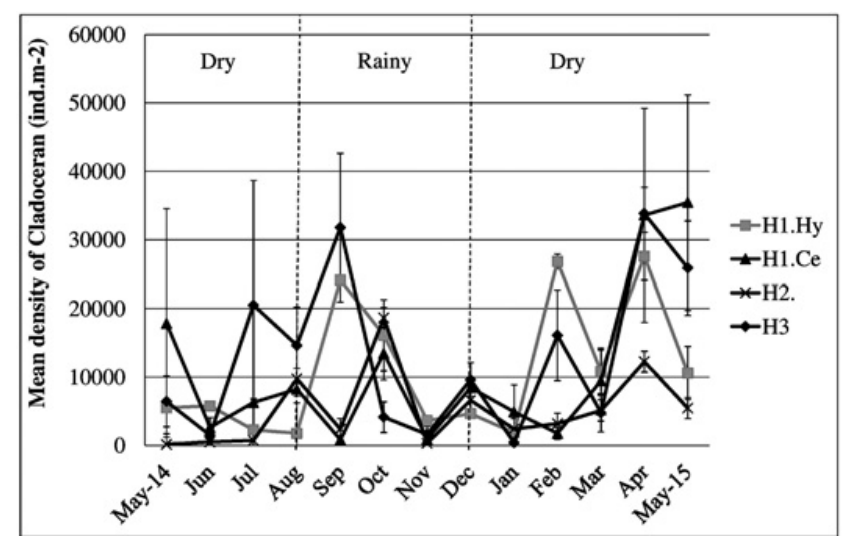

Fig. 6. Density of Cladocera in Thale-Noi Lake over consecutive seasons, total of all habitat traps. Overall peaks in density occur at mid-rainy season (September-October) and mid-dry season (February-April).

Sididae and Daphniidae) decreased, while smaller cladocerans appeared at lower densities when larger species peaked. In H1.Hy, A. harti (0.3-0.34 mm (Van Damme et al., 2011)) were found at a high density, while the comparatively larger species, L. australis (Up to $1.8 \mathrm{~mm}$ (Korovchinsky, 1992)) and C. cornuta $(0.39-0.45 \mathrm{~mm}$ (Idris, 1983)) showed low densities in June, September, February and April. On the contrary, A. harti showed lower density when L. australis began its high density in October. At the same time in H1.Ce, A. harti, E. barroisi and $K$. longirostris $(0.41-0.52 \mathrm{~mm}$ (Idris, 1983)) showed low density, while larger species L. australis occurred at higher density in May and October. E. barroisi and $K$. longirostris appeared in highest densities when L. australis showed very low density in March and May, respectively. In H2, D. crassa (up to $0.36 \mathrm{~mm}$ (Smirnov, 1996)) was dominant, while the comparatively larger species $C$. cornuta occurred at low density in October and December. In H3, E. barroisi showed a higher density than the larger species $M$. triserialis (Up to $0.6 \mathrm{~mm}$ (Smirnov, 1992)), L. australis and C. cornuta in July and April. After that, E. barroisi had lower densities when C. cornuta peaked in September. In addition, E. barroisi occurred at lower density when $M$. triserialis and L. australis reached high densities in December and February and E. barroisi decreased, while L. australis increased in May.

Among similarly sized Chydoridae, we noted that $A$. harti was usually found at low density when E. barroisi was at high density. This phenomenon was found in May and March in H1.Ce and in July, April and May in H3. On the other hand, A. harti appeared at high density when E. barroisi was low, which was found in October and April in H1.Ce and September in H3 (Fig. 8).

Most of the dominant species in each habitat peaked during the rainy season (September-October) and the dry season (April) (Fig. 8).
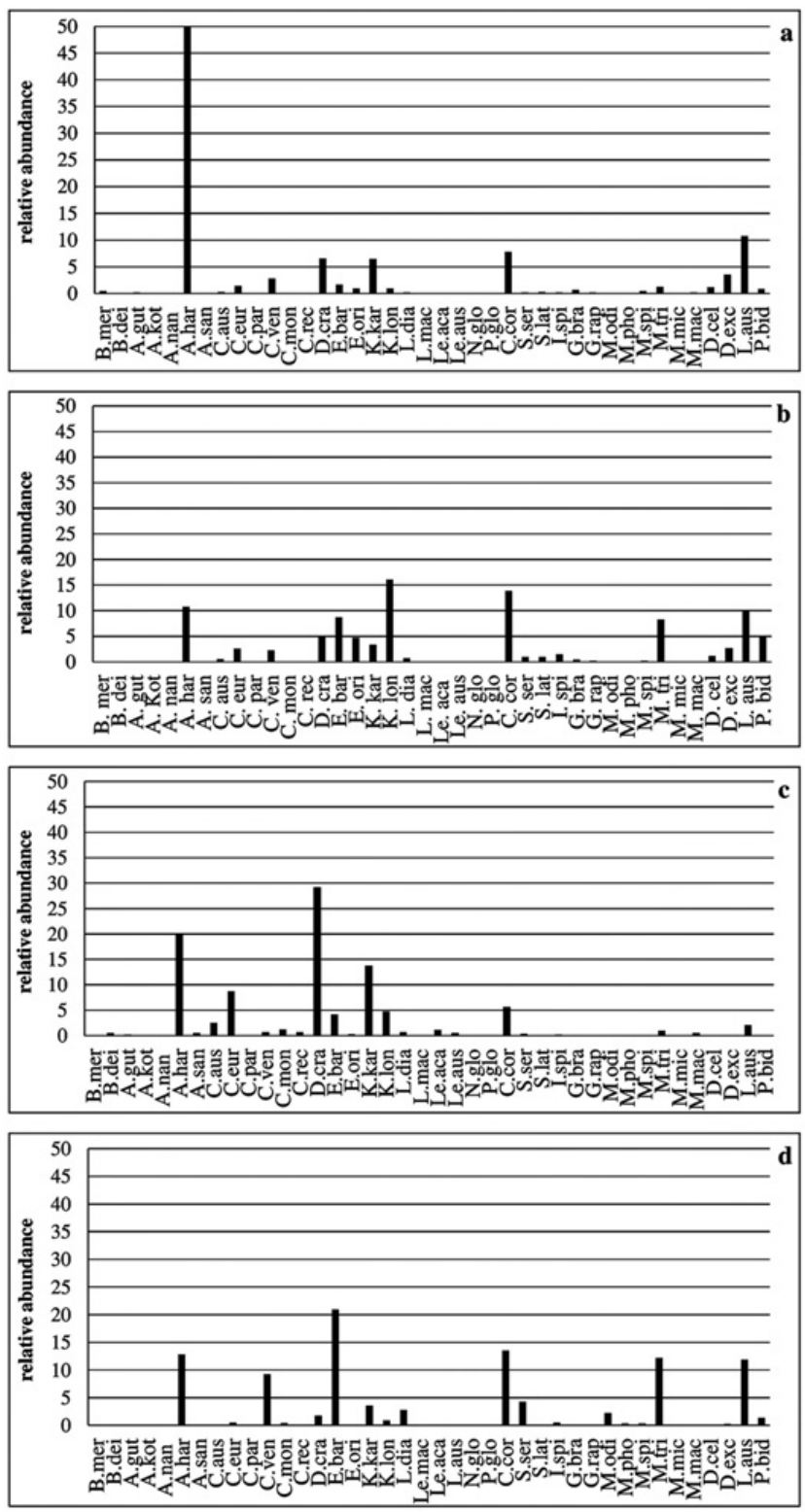

Fig. 7. Relative abundance of each cladoceran species in ThaleNoi Lake between May 2014 and May 2015. a: H1.Hy, b: H1.Ce, c: H2, d: H3. Species code; see Table 2.

\section{Cladoceran composition}

A simple cluster analysis showed that the cladoceran community composition could be divided into three groups according to the habitat (Fig. 9) as follows: Group 1: H2. The cladoceran community in Habitat 2 was not similar to the other groups. Group 2: H1.Hy and H1.Ce separated from Group 1. The cladoceran communities in these two habitats (the Ceratophyllum and Hydrilla patch) in $\mathrm{H} 1$ are 100\% similar. Group 3: H3 separated from Group 2. The cladoceran communities in Habitat 3 share about 50\% similarity with Group 2. Several species that occurred uniquely in each group were made up of mainly rare occurrences. A. kotovi, M. odiosa and $M$. pholpunthini were found only in Group 3. 

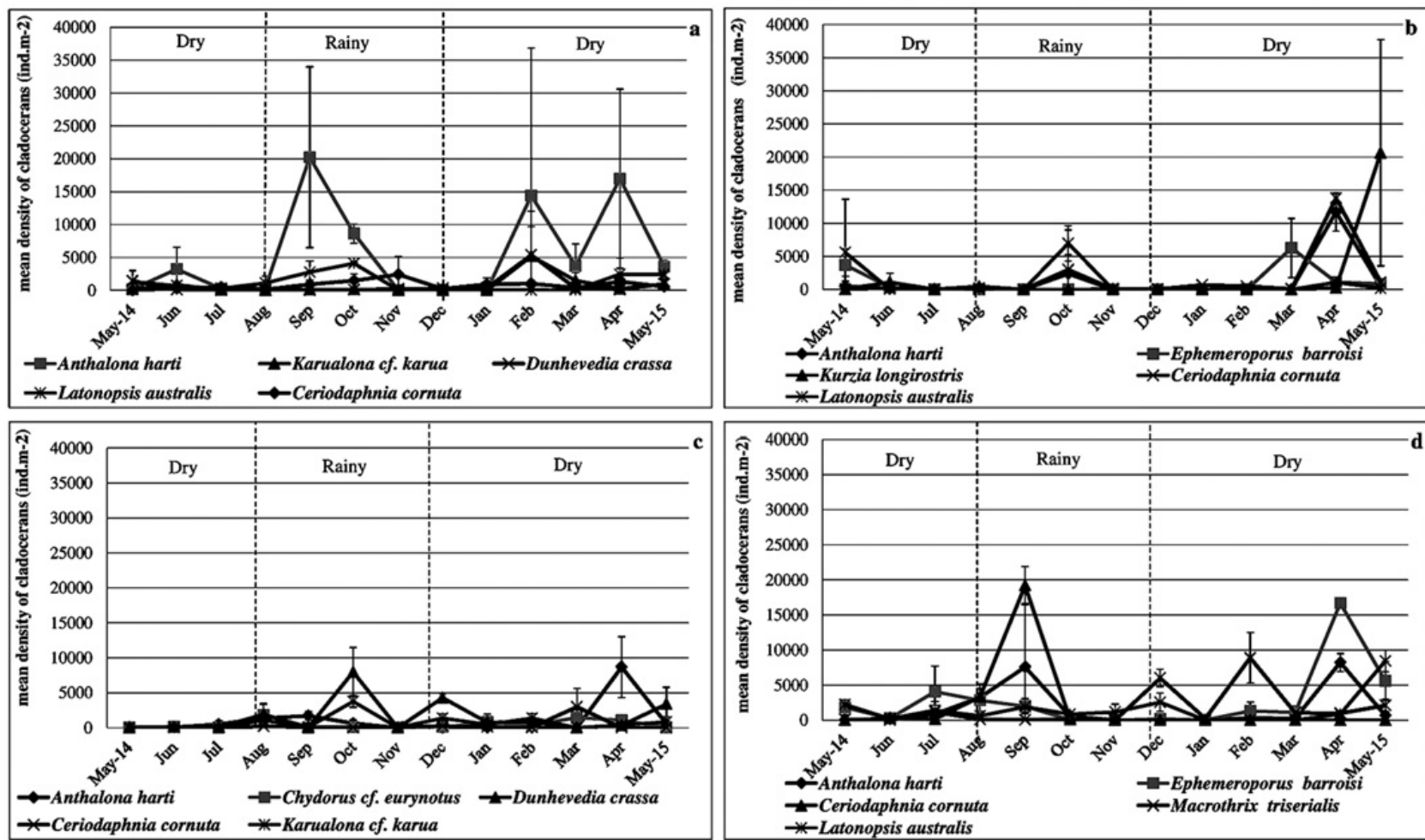

Fig. 8. Monthly fluctuations in density of the five most dominant Cladocera in each habitat in Thale-Noi Lake over 1 year (2014-2015) a; H1.Hy; b; H1.Ce, c; H2 and d; H3.

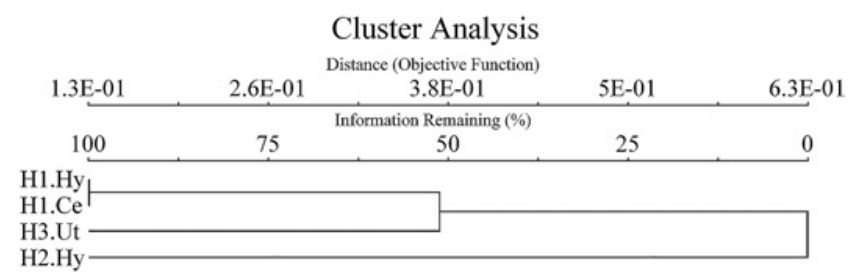

Fig. 9. Cluster analysis of the habitats distinguishes the three main habitat types, according to the cladoceran communities.

C. macronyx was found only in Group 2, while A. nana and $A$. sanoamuangae occurred only in Group 1.

\section{Species-environmental factors}

The CCA suggested that the cladoceran community and the environmental variables correlated significantly (Fig. 10). Eigenvalue Axis $1=0.432$, Axis $2=0.322$. The first axis explains $43.2 \%$ of the total variance and the second axis explains $32.2 \%$. The canonical eigenvalues accounted together for $74.6 \%$, Monte Carlo permutation test $P=0.016$, Pearson Correlation coefficient $r=0.840$; i.e., the $r$ value that represents the environmental variables in relation to cladoceran distribution is $84.0 \%$.

$\mathrm{pH}$ and depth are the environmental variables that showed the highest correlation with the cladoceran communities (pH Axis1 $r=-0.313, r^{2}=0.098$, Axis2 $r=-0.634, r^{2}=0.402$; depth Axis $1 r=0.726, r^{2}=0.527$,

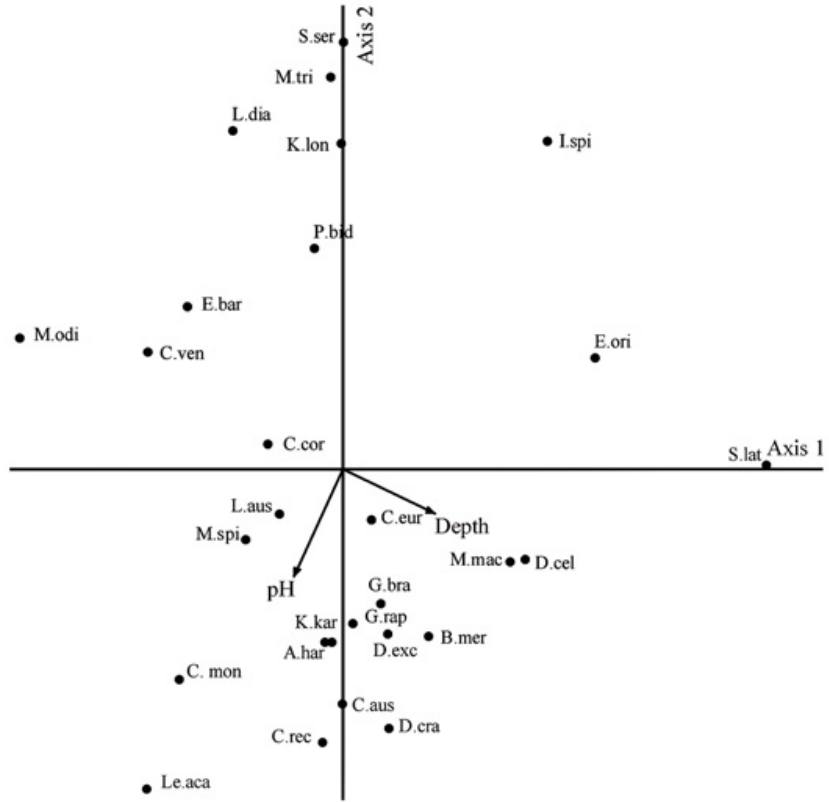

Fig. 10. The canonical correspondence analysis (CCA) ordination diagram for Cladocera assemblages showing species and environmental variables in Thale-Noi Lake. Species code; see Table 2 .

Axis2 $\left.r=-0.224, r^{2}=0.050\right)$. There is a high positive correlation between $\mathrm{pH}$ and a species cluster consisting of L. australis, M. spinosa, A. harti, Karualona cf. karua, Camptocercus cf. australis, Coronatella cf. rectangula, 
Coronatella cf. monacantha and L. acanthocercoides. Most of them have been found at $\mathrm{pH}$ ranges between 7.11 and 10.17, whereas I. spinifer, E. orientalis and Simocephalus latirostris showed a negative correlation with $\mathrm{pH}$, distributed at $\mathrm{pH}$ ranges between 3.58 and 8.48. Depth showed high positive correlation with Chydorus cf. eurynotus, D. celebensis, M. macleayi, G. brazzai, G. raphaelis, D. excisum, Bosmina meridionalis and D. crassa. They are found in depth ranges between 1.1 and $2.05 \mathrm{~m}$, while $M$. triserialis, L. diaphanus, $K$. longirostris, P. bidentata, E. barroisi, C. ventricosus, $M$. odiosa and $C$. cornuta showed negative correlation with depth and were found at shallower conditions with depth ranges between 0.7 and $1.1 \mathrm{~m}$. Moreover, the correlation test found that total cladoceran density (the sum of all samples in three traps) in H3 (Utricularia patches) showed negative correlation with depth $(P=0.03$, Spearman Correlation Coefficient; $\quad r=-0.750$ (Correlation test)). Density in this patch was the lowest in November and January (1633 and 400 ind. $\mathrm{m}^{-2}$ ) when the lake was the deepest $(1.7 \mathrm{~m})$, while they showed the highest density with low depth (0.63-0.9 m) during September, July, April, February and December.

\section{Discussion}

\section{Species diversity}

We retrieved 40 species through the activity traps, comprising $85 \%$ of the total number of Cladocera recorded for Thale-Noi, $71 \%$ of the previously reported Chydoridae and $100 \%$ of the Daphniidae, Ilyocryptidae and Moinidae. For Bosminidae, Macrothricidae and Sididae, we collected new records for the lake that were overlooked in previous studies (Pholpunthin, 1997; Maiphae, 2005; Inpang, 2008). With this study, the total number of cladoceran species in Thale-Noi Lake increased from 47 to 58 and cladoceran diversity in the South of Thailand increased from 86 to 87 species and over the whole country from 108 to 109 species compared to the most recent estimates (Maiphae, 2008; Van Damme et al., 2013). With recent revisions and descriptions of new species in the region, this number is likely to increase as widely used names of cosmopolitan or circumtropical species complexes with cryptic diversity will be updated (e.g.,Korovchinsky, 2013).

D. celebensis is a new record, expected to occur in Thailand and found in the neighboring regions of Vietnam and Malaysia (Korovchinsky, 2013). A. kotovi is a taxonomical update with confirmed identity, which replaces previous records of its sister species (A. quadrangularis) in Thale-Noi and most likely the rest of Thailand (the latter species seems restricted to the Palaearctic) (Sinev, 2012). Records from Thale-Noi (and most of Thailand) previously labeled Alona verrucosa are updated here, since taxonomic revisions in this group revealed new species in the region (Van Damme et al., 2011; Sinev and Kotov, 2012). Two species were clearly distinguished in Thale-Noi as $A$. sanoamuangae and $A$. harti, both previously recorded in Thailand (Sinev and Kotov, 2012). This study demonstrated that these species have very distinct ecologies, with $A$. harti the most common. The identity of another "new" record for Thailand, replacing a previous one, could not yet be confirmed, listed here still as Pseudochydorus cf. globosus, although this is most likely the South East Asian sibling Pseudochydorus bopingi Sinev et al. (2016). P. globosus is another widespread species complex, with yet unresolved species in South America and Africa (Van Damme and Dumont, 2007). For several other records, local populations remain unrevised. Therefore, general assignments to species groups are used for now, for example in Alona, Coronatella (Alona guttata, Coronatella cf. monacantha, Coronatella cf. rectangula), Chydorus (Chydorus cf. eurynotus) and many others. Some records need closer attention, such as $P$. bidentata, an American taxon which needs to be revised locally, in comparison with the common tropical Asian sibling Pseudosida szalayi Daday, 1898 (Korovchinsky, 2010). A similar case can be made for our records, currently falling under the American name Chydorus cf. eurynotus in South East Asia, which may comprise more than one species (Sinev, 2014). Indeed, there are several species, in some cases with existing names, in need of local revision (e.g., Coronatella acuticostata instead of Coronatella cf. monacantha; Van Damme et al., 2010; Van Damme, 2016). Most importantly, their ecologies should not necessarily be seen as completely identical to similar species (for now known under the same name) that occur outside South East Asia. Anthalona (the former $A$. verrucosa group) is a good example of how different such ecologies may be, even within the same lake, as seen in this study.

Six species were restricted to a single habitat and rarely found in this study. These are not typical lake species. They were all listed among paludal Cladocera in southern Thailand (Van Damme et al., 2013) and seem to enter the lake sporadically from surrounding areas (inlet) with locally low density. They include a few individuals of A. kotovi, A. nana (once), C. macronyx and $A$. sanoamuangae (twice), $M$. odiosa (three times) and $M$. pholpunthini (four times). M. odiosa was recorded in swamps at Chakradharpur, Chaibassa District, Chota Nagpur, India (Gurney, 1907) and reported from Perendeniya pond and Anuradhpura in Sri Lanka (Gurney, 1916). M. odiosa occurs in lakes in North East Thailand (Saeng-aroon and Sanoamuang, 2002) and in swamps in Southern Thailand (Maiphae, 2005), also listed among the swamp cladocerans (Van Damme et al., 2013). M. pholpunthini is a paludal species found in Thailand at only two localities in Trang Province, Yon and Natam swamps (Van Damme et al., 2013). A. sanoamuangae is present in the Mekong River, Mukdahan Province, Thailand and in Vietnam (Sinev and Kotov, 2012) and seems more widespread in the region. This study confirms that shallow lake habitats are not their primary preference, and that they are rare specialists within Thale-Noi, sporadically occurring in areas with low $\mathrm{pH}$. 
The species richness found in the activity traps was higher than recorded by qualitative methods for the same lake by Pholpunthin (1997) (17 species) and Maiphae (2008) (15 species) due to sampling method and frequency. Pholpunthin (1997) collected samples only once and Maiphae (2008) sampled four times (two times in each season) using plankton nets. The results from this study and Inpang (2008) produced similar numbers (40 and 41 spp., respectively) from samples collected throughout the year. However, 13 species of cladocerans were recorded for the first time from Thale-Noi, showing the effectiveness of the activity traps for benthic species. Samples collected using plankton nets usually missed several of the benthic/phytophilic species. Using funnel traps, we found A. kotovi and Leydigia, which are sediment-dwelling chydorids (Moore, 1939; Flössner, 1964; Fryer, 1968; Smirnov, 1971; Evans, 1984).

As expected from shallow, well-vegetated lakes, the Chydoridae formed the most diverse group (22 species), followed by representatives of the Macrothricidae (6 species) and Sididae (4 species). Total species richness over 1 year gave similar numbers for each of the habitats (30-34 species), with 26 species shared between the sites. This indicates that total richness is not dependent on the type of macrophyte. Walseng et al. (2008) reported that the number of cladoceran species and copepods in 21 Canadian Shield lakes showed only minor differences between floating leaf and submerged macrophyte habitats (Eriocaulon septangulare (With.)). However, species richness in Thale-Noi seems to fluctuate temporally, with two- to three-fold increases in each of the habitats and sometimes between consecutive months. Although we sampled only 1 year, the littoral Hydrilla and Ceratophyllum beds showed significantly higher species richness in the dry season (21-22 species) than in the rainy season (7-8 species), linked with changes in water transparency (significantly higher in the dry season). Thale-Noi is a shallow lake with a depth of $0.8-2.1 \mathrm{~m}$. Turbidity increases strongly during the rainy season. This affects the light intensity, limiting epiphyton and phytoplankton, as turbidity and light penetration are inversely related (Michaud, 1991). Therefore, high solar radiation encourages productivity in tropical lakes (Talling and Lemoalle, 1998). Species richness in the open water habitat deeper zones $(1.05-2.05 \mathrm{~m})$ with fewer macrophytes showed the opposite trend and higher species richness during the rainy season (17 species) than in the dry season (5 species). The rare occurrences $A$. nana and A. sanoamuangae appeared in small numbers only during the rainy season in this locality, whereas Leydigia australis, a strictly benthic species, dominated during the rainy season, together with more generalist species such as D. crassa and Chydorus cf. eurynotus, which showed a high correlation with depth.

However, it is not possible to speak of truly "seasonal patterns" over such a short study period. Species richness differed strongly between consecutive years in some habitats for the same period (H2; 5 and 12 species, H3; 10 and 20 species in May 2014 and 2015, respectively).
This might be due to fluctuations in environmental factors (e.g., depth, $\mathrm{pH}$ and salinity), which may influence species diversity (Fig. 3). However, in general, we found the short-term fluctuations of cladoceran species richness throughout the year in Thale-Noi Lake more pronounced than expected and the data seem to suggest some seasonality in zooplankton density across the lake.

There is a general misconception that all tropical lakes are relatively uniform and stable throughout the year (Twombly, 1983). It may seem that zooplankton in tropical lakes is not as subject to seasonal fluctuations as in temperate lakes, but shallow tropical lakes have pronounced effects from seasonal rainfall regimes (Melack and Kilham, 1974; Hart, 1985; Talling and Lemoalle, 1998). The same is true for river deltas, where Cladocera diversity and density are highly influenced by precipitation (Borges and Pedrozo, 2009). Short-term effects on cladoceran species richness are pronounced in Thale-Noi. Temporal variation of zooplankton species richness, density and community structure in shallow tropical lakes require studies over a longer time period than a single year to effectively assess truly seasonal trends.

\section{Density}

The overall cladoceran density was significantly lower in the open water habitat than in more littoral areas. Relatively lower density of Cladocera in the pelagic zone (with less vegetation cover on the bottom) in Thale-Noi has been recorded before with different sampling methods (Inpang, 2008). Littoral zones provide a more diverse environment and richer food source for Cladocera, as well as more efficient refuge areas from predators in comparison to more open water zones (Whiteside and Harmsworth, 1967; Stansfield et al., 1997; Geraldes and Boavida, 2004). However, most comparisons in cladoceran density between littoral and pelagic zones in lakes are based on limited sampling and ignore bottom-inhabiting species. Using the activity traps, the density (and diversity) of cladocerans in a shallow lake can be approached with more robustness. The substrate in the open water areas of Thale-Noi is largely covered by Hydrilla, providing opportune niches. However, the environment is not as sheltered here as in the littoral areas and cladoceran densities do not reach as high as in the more marginal sites. The density of floating vegetation in open water is also very low as a result of wind and wave action (Inpang, 2008). However, the total species richness here is similar over the course of a year. A lower cladoceran density in the open water is also likely due to higher fluctuations in depth, $\mathrm{pH}$ and salinity compared with the littoral zone. An increase in salinity results in drastic changes in community structures. Freshwater species must cope with salinity stress in a manner proportional to their degree of tolerance. Salinity may cause a significant reduction in fecundity and a developmental delay as well as a decrease in the growth rate in cladocerans, e.g., in non-adapted daphniid populations (Gonçalves et al., 2007). In addition, 
cladoceran density is strongly correlated with depth and $\mathrm{pH}$ with significant difference between the pelagic $(\mathrm{H} 2)$ and littoral areas (Utricularia habitat; $\mathrm{H} 3$ ).

In total 26 species showed significant differences in density depending on the habitat. Coronatella cf. rectangula showed the highest dominance in the open area, which is covered with a thick detritus layer. Leydigia species are known as mud-dwellers (Flössner, 1964; Fryer, 1968; Adamczuk, 2014). Therefore, L. acanthoceroides and L. australis were the most abundant in the benthos of the open area in Thale-Noi. This is rich in thick detritus in the deep areas (1.05-2.05 m) and L. australis showed significantly higher density during the rainy season than in the dry season. Another sediment-dwelling chydorid, A. kotovi, was only found in the Utricularia patch. The sibling species, A. quadrangularis, is mainly a benthic chydorid (Moore, 1939; Flössner, 1964; Smirnov, 1971; Whiteside, 1974; Whiteside et al., 1978; Evans, 1984).

The habitat preference of cladocerans seems to depend mainly on depth and $\mathrm{pH}$ in Thale-Noi. Latonopsis australis, Chydorus cf. eurynotus and D. crassa were dominant in the open water area with the high depth of 1.05-2.05 m. These species showed a high positive correlation with depth in a CCA analysis and were found at a depth range of 1.1 and $2.05 \mathrm{~m}$. On the other hand, C. ventricosus, E. barroisi, L. diaphanus, C. cornuta and $M$. triserialis were found in the highest density in the littoral Utricularia beds with the lowest depth $(0.63-1.7 \mathrm{~m})$. The CCA analysis confirmed that these species showed high negative correlation with depth and were found between 0.7 and $1.1 \mathrm{~m}$.

Several species were abundant in all habitats studied. We consider them the main cladoceran inhabitants of the lake's substrate and vegetation. The chydorids A. harti, E. barroisi, K. longirostris, D. crassa and Karualona cf. karua, the daphniid C. cornuta and the ctenopod L. australis were the most common cladocerans in Thale-Noi, reaching high individual densities and dominance per habitat. Like most well-vegetated shallow tropical lakes without a strongly developed pelagic, Thale-Noi is dominated in density and species richness by chydorids, whereas daphniids are less diverse and seem less abundant (at least, using the activity traps). Considering their density in Thale-Noi, chydorids will play a significant role as major components of the aquatic food web. Nevertheless, there are several dominant species also among daphniids and ctenopods. A few of these common species can be considered as having a non-specific relationship to the environmental variables studied (see CCA plot), such as L. australis and C. cornuta, whereas common chydorids seem to be sensitive to $\mathrm{pH}$. Differences in $\mathrm{pH}$-preferences and tolerance may therefore allow for high chydorid diversity and coexistence within the lake, within the fluctuating temporal and spatial gradients of this ecological parameter. In areas or times of lower $\mathrm{pH}$, $K$. longirostris and E. barroisi seem to increase in density in the communities, whereas A. harti, D. crassa and Karualona cf. karua species take over under relatively higher $\mathrm{pH}$ levels.
Total cladoceran density peaked in Thale-Noi during the rainy season (September-October) and the dry season (April-May), with the lowest overall density occurring in June, November and January. These fluctuations could be linked to the environmental variables. Our study found that total cladoceran density in Ceratophyllum patches positively correlated with water temperature and oxygen levels. The highest total cladoceran density was in May $\left(35444 \pm 15711\right.$ ind. $\mathrm{m}^{-2}$ ) under the highest temperature of $34.7^{\circ} \mathrm{C}$, dissolved oxygen $7.17 \mathrm{mg} \mathrm{O}_{2} \cdot \mathrm{L}^{-1}$ and lowest density was in September $\left(844 \pm 51\right.$ ind. $\left.\mathrm{m}^{-2}\right)$ at the lowest temperature $27.4{ }^{\circ} \mathrm{C}$ and dissolved oxygen $4.80 \mathrm{mg} \mathrm{O}_{2} . \mathrm{L}^{-1}$. We found that $K$. longirostris, a widespread circumtropical chydorid, was the most abundant $\left(1743 \pm 6788\right.$ ind. $\left.\mathrm{m}^{-2}\right)$ in this habitat. This species reached a peak in May, but it was absent in September, October, January, February and March. Temperature is related to the duration of egg development and the growth of Cladocera (Bottrell, 1975; Vijverberg, 1980). Filter feeding species $C$. cornuta and L. australis were among the most dominant in the Ceratophyllum patch under warmer conditions. Geller (1975), Gophen (1976) and Kersting and Van Der Leeuw (1976) suggested that higher temperatures increase filtering rates in cladocerans. The influence of temperature might be difficult to assess in a shallow lake, which is a well-mixed body of water with minor differences in temperature between surface and bottom (Mourelatos and Lacroix, 1990).

Fifteen species $(37.5 \%)$ showed potential differences in terms of density between the seasons. This indicated that while most species might profit from better conditions during the relatively short dry and rainy seasons, their density is influenced by biotic factors (predation, competition, life history). For example, Chydorus cf. eurynotus had a higher density in the dry season than in the rainy season. When compared, the two seasons did not show a significant difference in total density or changes in environmental variables, except for turbidity in the littoral Hydrilla beds. However, there was a significant difference between the dry/rainy season and the other months. Güntzel and Panarelli (2010) reported that the most important factors determining species distribution in oxbow lakes in Brazil are seasonal variation in rainfall, nutrients (chlorophyll, nitrogen and phosphorus), water transparency, dissolved oxygen, water temperature and electrical conductivity. Nevalainen (2012) suggested that temperature also plays a role in chydorids. Oxygen concentration is an important factor controlling the distribution and community structure of zooplankton in lakes (Wright and Shapiro, 1990; Hanazato, 1992). However, as stated earlier, we cannot determine a recurrent seasonal trend since our data only span a single year, only that the highest overall density in this particular year corresponded to the dry and rainy seasons.

Individual species reached high densities. Total maximum peaks were 160333 ind. ${ }^{-2}$ (mean; $35444 \pm 15711$ ind. $\mathrm{m}^{-2}$ ) for all Cladocera for a single sampling. The dominant species (A. harti, K. longirostris, D. crassa and E. barroisi) peaked between 1858 
and 60667 ind. $\mathrm{m}^{-2}$ (mean; $619 \pm 512$ and $20222 \pm$ 13743 ind. $\mathrm{m}^{-2}$ ) per night during dry and/or rainy seasons. Mean chydorid density in the four macrophyte patches ranged between $4638 \pm 852$ and $7875 \pm$ 307 ind. $\mathrm{m}^{-2}$. These are lower numbers compared with cladoceran densities at the temperate Plastic Lake in Ontario, Canada (using the same sampling method), where the density of Chydoridae in four different habitats showed mean ranges between 5000 and 17097 ind.m ${ }^{-2}$ (Tremel et al., 2000). Therefore, the lower limit is fairly similar, yet the upper limit is not. Although cladoceran density in this study was lower than that reported by Tremel et al. (2000), species richness is similar. We found an average of 22 chydorid species in each habitat, while Tremel et al. (2000) reported 20 species. The higher maximum density of cladocerans recorded by Tremel et al. (2000) could be explained by the sampling frequency and traps used (15 traps per habitat over 3 consecutive days versus 3 traps per habitat over 1 day in our study). Cladoceran densities may reach high numbers in general. Smirnov (1974) noted that millions of individuals of Chydorus may occur per $\mathrm{m}^{2}$ in temperate lakes, yet we found total Chydorus in all macrophyte patches with an average of 2569 ind. $\mathrm{m}^{-2}$. Besides potential errors in density estimation, it could be possible that lower density has an ecological cause. Generally, lower density of zooplankton is expected in tropical versus temperate lakes due to higher prevalent predation levels in the former (Dumont, 1994). Predatorprey dynamics were not considered in this study.

\section{Habitat preference and environmental relationship}

The cladoceran community was similar in composition and density in different macrophyte beds in the same zone (communities are $100 \%$ similar between Hydrilla and Ceratophyllum patches in $\mathrm{H} 1$ ), whereas the same macrophyte species in a different zone showed marked differences (the cladoceran community in Hydrilla beds in the littoral was not similar to the community in Hydrilla beds in the open water zone). Tremel et al. (2000) suggested that cladoceran density is influenced by factors other than vegetation. Our results confirm that different species with similar plant morphology, all fine-dissected, submerged macrophytes, have little effect on cladoceran community compositions in comparison to other factors.

The cladoceran communities differed the most between the open water zone and the marginal zones. The structure of cladoceran communities was mainly correlated with depth and $\mathrm{pH}$. There is a high positive correlation between $\mathrm{pH}$ and $L$. australis, M. spinosa, A. harti, Karualona cf. karua, Camptocercus cf. australis, Coronatella $\mathrm{cf}$. rectangula, Coronatella $\mathrm{cf}$. monacantha and $L$. acanthocercoides. Most of these were found at $\mathrm{pH}$ ranges between 7.11 and 10.17 . This is consistent with Inpang (2008), who reported that $\mathrm{pH}$ was highly correlated for at least two of these taxa (Latonopsis and Macrothrix). Nachai (2006) suggested pH as the main factor in cladoceran distribution for Coronatella cf. rectangula and Coronatella cf. monacantha (found at $\mathrm{pH}>6.9$ ) and Sa-ardrit (2002) proposed that $M$. spinosa and Anthalona sp. occurred in habitats with a $\mathrm{pH}$ higher than 7.1. Indeed, $\mathrm{pH}$ is a strong factor governing zooplankton species composition in the littoral (e.g., copepods and cladocerans; Walseng et al., 2008) and in general, acidity exerts a determining influence on the composition and diversity of freshwater faunas (Weber and Pirow, 2009). $\mathrm{pH}$ is also an important factor in the distribution of Chydoridae on a geographical scale (de Eyto et al., 2003). On the other side of the spectrum, some species are better adapted to low $\mathrm{pH}$. We found I. spinifer, E. orientalis and $S$. latirostris distributed at generally lower $\mathrm{pH}$ ranges between 3.58 and 8.48 .

Depth, as the second most important variable, showed high positive correlation with several cladocerans that venture into the open water (1.1-2.05 m) of Thale-Noi such as Chydorus cf. eurynotus, D. celebensis, M. macleayi, G. brazzai, G. raphaelis, D. excisum, B. meridionalis and $D$. crassa. Nachai (2006) reported that cladocerans such as Diaphanosoma were associated with high depth. On the other hand, M. triserialis, L. diaphanus, $K$. longirostris, $P$. bidentata, E. barroisi, $C$. ventricosus, $M$. odiosa and $C$. cornuta seemed to prefer shallower conditions $(0.7-1.1 \mathrm{~m}$.). In addition, we found that the monthly fluctuation of total Cladoceran density in the littoral Utricularia patch showed a negative correlation with depth, with $M$. triserialis, L. diaphanus, E. barroisi, $C$. ventricosus, $M$. odiosa and $C$. cornuta being the dominant species when water levels were lower. Therefore, there seem to be subtle niche separations between morphologically (apparently) similar species such as $C$. ventricosus and Chydorus cf. eurynotus. They have similar external morphology, but prefer different niches. C. ventricosus is correlated with low depth, therefore more of a littoral species, whereas Chydorus cf. eurynotus is associated with high depth, reducing interspecific competition.

Indeed, depth is an important factor in lakes even within the littoral zone (e.g., benthic chydorids; Adamczuk, 2014). In general, many cladoceran species are influenced (Korhola et al., 2000; Amsinck et al., 2006) by depth, which provides different niches (Chittapur, 2009). Chydoridae show different patterns of distribution in homogeneous lakes along the lake depth determined by UV exposure, thermal properties, food resources and predators (Nevalainen, 2012).

\section{Population changes}

We did not examine biotic interactions in detail. However, monthly fluctuations in several species may result from competitive interactions. The fact that there is a similar maximum diversity at any given time per habitat (17-22 species) indicates a limit to the number of cladoceran species that can coexist within a certain niche of the dimensions studied here. Therefore, competition and food limitations must play a role. Competitive interaction could occur between the most dominant 
chydorids (Anthalona, Ephemeroporus, Karualona, Kurzia, Chydorus, etc.). For example, we noted that $A$. harti usually occurs at low densities when $E$. barroisi is abundant, and vice versa, in all habitats (Fig. 8). This merits further study, combined with laboratory experiments, to assess competitive interactions under different conditions. Descriptions of competitive interactions among cladocerans have been limited primarily to pelagic species (DeMott and Kerfoot, 1982; Kerfoot et al., 1985; Vanni, 1986), leaving the competitive interactions among Chydoridae virtually unstudied. However, not only typical littoral phytophilic-benthic species such as chydorids interact at the bottom of the lake during the daytime. All vertically-migrating cladocerans compete for available resources within a limited space and more pelagic species enter the competition (Bosminidae, Daphniidae, pelagic Ctenopoda, etc.). Thus, some littoral species can easily venture into the open water and feed on available food sources, while many filter-feeding species likewise have to compete with the bottom dwellers when moving down. Several specialists with a very specific niche (e.g., Ilyocryptus and Leydigia) occurred in the traps in considerable densities, all moving up during the night. The interactions of migrating benthic cladoceran communities have not been considered in tropical (or temperate) limnology, as the focus of most studies mainly lies on pelagic species.

Cladocerans display a wide range of body sizes. We speculate that smaller cladoceran species increase in density in Thale-Noi when the larger species are less abundant and vice versa, e.g., Anthalona, Ephemeroporus and Kurzia on the one hand versus Macrothrix, Latonopsis and Ceriodaphnia on the other. This could be explained by the size-efficiency hypothesis of Brooks and Dodson (1965), which suggests that large species are more competitive than small-sized species when feeding on the same resources (e.g., Bosminidae versus Daphniidae). Such interactions have not been studied in detail for Chydoridae versus Daphniidae or Macrothricidae, which might compete strongly in shallow tropical lakes.

\section{Conclusion}

We studied the community composition, density and species richness of Cladocera in Thale- Noi, a shallow tropical lake, over 1 year using activity traps. The main conclusions are:

1.The dominant cladoceran species in Thale-Noi include the chydorids $A$. harti, K. longirostris, D. crassa and $E$. barroisi, the ctenopod $L$. australis, the daphniid $C$. cornuta and the macrothricid $M$. triserialis. Of the 40 species retrieved in our study $(85 \%$ of the total known diversity for the lake), half are chydorids. Members of the Chydoridae reach individual densities of up to $20222 \pm 13743$ ind. $\mathrm{m}^{-2}$ per night for a given site (A. harti, September, H1.Hy), making up an essential component of the littoral/benthic invertebrate biomass in shallow tropical lakes. We confirm that in tropical shallow lakes, chydorids play a dominant role over daphniids and these groups may enter into direct competition with one another.

2.Among the factors studied, the Cladocera of Thale-Noi are primarily influenced by $\mathrm{pH}$ and depth. Although only few sites were compared, it is possible that under similar conditions but in different macrophyte stands, the cladoceran communities may not change, yet under dissimilar conditions but with the same macrophyte species, the cladoceran communities may differ.

3. We noticed a temporal variation (between months over a single year) in cladoceran species richness and density, yet a similar maximum richness of species coexisting at any given time for each habitat (max. 22 species). There could be a seasonal pattern in species density and richness, with strong density peaks during the dry and wet seasons, but our sampling period is too limited. Overall, total densities of cladocerans in this shallow tropical lake seem lower than in temperate lakes (applying the same method).

4.Application of the activity traps to study zooplankton in shallow tropical lakes allows a better understanding of the diversity, the dynamics and the importance of a large and strongly underestimated component in tropical lakes, the littoral/benthic Cladocera. We recommend such a sampling for long-term zooplankton studies in shallow tropical lakes; however the method can certainly be improved.

Acknowledgements. We would like to thank Asst. Prof. Dr Veerasak Punyapornwithaya, Chiangmai University for guiding us in using the $\mathrm{R}$ Program. Thanks to Dr Árni Einarsson for his detailed explanation and photographs of the Myvatn Cladocera trap, which formed the basis for our activity traps. This research was supported financially by the Research Assistant Scholarship (RA), Faculty of Science, National Research University grant (NRU) and grant from the Graduate School, Prince of Songkla University.

\section{References}

Adamczuk M., 2014. Niche separation by littoral - benthic Chydoridae (Cladocera, Crustacea) in a deep lake - potential drivers of their distribution and role in littoral - pelagic coupling. J. Limnol., 73, 490-501.

Aiumnau A., Bunpapong S. and Office of Environmental Policy and Planning, 2000. Biodiversity of Thale-Noi Wetland, Office of Environmental Policy and Planning, Bongkok Press, Thailand, 130 p. (in Thai).

American Public Health Association, American Water Works Association and Water Environment Federation (APHA, AWWA, and WEF), 1998. Standard Method for the Examination of Water and Wastewater, American Public Health Association, Washington, DC.

Amsinck S.L., Strzelczak A., Bjerring R., Landkildehus F., Lauridsen T.L., Christoffersen K. and Jeppesenx E., 2006. Lake depth rather than planktivory determines cladoceran community structure in Faroese lakes - evidence from 
contemporary data and sediments. Freshw. Biol., 51, 2124-2142.

Angsupanich S. and Rakkheaw S., 1997. Seasonal variation of phytoplankton community in Thale Sap Songkhla, a lagoonal lake in southern Thailand. Netherlands J. Aquatic Ecol. 30, 297-307.

Angsupanich S., Siripech A. and Charoenpornthip M., 2005. Macrobenthic fauna community in the middle Songkhla Lake, Southern Thailand. Songklanakarin J. Sci. Technol., 27, 365-390 (in Thai).

Artharamas C., 1984. Survey of Aquatic Macrophytes in Thale-Noi, Department of Biology, Faculty of Science, Prince of Songkla University, 59 p.

Barton D.R. and Carter J.C.H., 1981. Shallow-water epilithic invertebrate communities of eastern Georgian Bay, Ontario, in relation to wave action. Can. J. Zool., 60, 984-993.

Belyaeva M. and Deneke R., 2007. Colonization of acidic mining lakes: Chydorus sphaericus and other Cladocera within a dynamic horizontal $\mathrm{pH}$ gradient $(\mathrm{pH} 3-7)$ in Lake Senftenberger See (Germany). Hydrobiologia, 594, 97-108.

Borges M.G. and Pedrozo C.S., 2009. Zooplankton (Cladocera, Copepoda and Rotifera) richness, diversity and abundance variations in the Jacuí Delta, RS, Brazil, in response to the fluviometric level. Acta Limnol. Bras., 21, 101-110.

Bottrell H.H., 1975. The relationship between temperature and duration of egg development in some epiphytic Cladocera and Copepoda from the River Thames, reading, with a discussion of temperature functions. Oecologia (Berl.), 18, 63-84.

Brooks J.L. and Dodson S.I., 1965. Predation, body size and composition of plankton. Science, 150, 28-35.

Chittapur S., Pholpunthin P. and Sanoamung L., 2009. Diversity and composition of zooplankton in rice fields during a crop cycle at Pathum Thani province, Thailand. Songklanakarin J. Sci. Technol., 31, 261-267.

de Eyto E., Irvine K., Garcia-Criada F., Gyllström M., Jeppesen E., Kornijów R., Miracle R.M., Nykänen M., Bareiss C., Cerbin S., Salujõe J., Franken R., Stephens D. and Moss R., 2003. The distribution of chydorids (Branchiopoda, Anomopoda) in European shallow lakes and its application to ecological quality monitoring. Arch. Hydrobiol, 156, 181-202.

DeMott W.R. and Kerfoot W.C., 1982. Competition among cladocerans: nature of the interaction between Bosmina and Daphnia. Ecology, 63, 1949-1966.

Di Fonzo C.D. and Campbell J.M., 1988. Spatial partitioning of microhabitats in littoral Cladoceran communities. J. Freshw. Ecol., 4, 303-313.

Dodson S.I. and Frey D.G., 1991. Cladocera and other branchiopoda. In: Thorp J.H. and Covich A.P. (eds.), Ecology and Classification of North American Freshwater Invertebrates, Academic Press, 723-786.

Dumont H.J., 1994. On the diversity of the Cladocera in the tropics. Hydrobiologia, 272, 27-38.

Dumont H.J. and Silva-Briano M., 2000. Karualona n.gen. (Anomopoda: Chydoridae), with a description of two new species, and a key to all known species. Hydrobiologia, 435, 61-82.

Evans M., 1984. Benthic and epibenthic (microcustaceans, macrobenthos) community structure in the vicinity of a power plant, Southeastern Michigan. Verh. Int. Ver. Limnol., 22, 488-494.
Fernando C.H., 1980. The species and size composition of tropical freshwater zooplankton, with special reference to the oriental region (South East Asia). Int. Rev. Gesamten Hydrobiol. Hydrogeogr., 65, 411-425.

Flössner D., 1964. Zur Cladoceren fauna des Stechlinsee Gebietes II. Okologische Untersuchungen uber die litoralen Arten. Limnologica, 2, 35-103.

Fryer G., 1968. Evolution and adaptive radiation in the Chydoridae (Crustacea Cladocera) A study in comparative functional morphology and ecology. Phil. Trans. Soc. B, 254, 221-335.

Geller V.W., 1975. Food ingestion of Daphnia pulex as a function of food concentration, temperature, animal's body length and hunger. Arch. Hydrobiol. Suppl., 48, 47-107.

Geraldes A.M. and Boavida M.J., 2004. Do littoral macrophytes influence crustacean zooplankton distribution? Limnetica 23, 57-64.

Gonçalves A.M.M., Castro B.B., Pardal M.A. and Gonçalves F., 2007. Salinity effects on survival and life history of two freshwater cladocerans (Daphnia magna and Daphnia longispina). Limnology 43, 13-20.

Gophen M., 1976. Temperature dependence of food intake, ammonia excretion and respiration in Ceriodaphnia reticulata (Jurine) (Lake Kinneret, Israel). Freshw. Biol., 6, 451-455.

Groom M.J., Meffe G.K. and Carrol C.R., 2006. Principles of Conservation Biology (3rd edn,), Sinauer Associates, USA, $779 \mathrm{p}$.

Guevara G., Lozano P., Reinoso G. and Villa F., 2009. Horizontal and seasonal patterns of tropical zooplankton from the eutrophic Prado Reservoir (Colombia). Limnologica, 39, 128-139.

Güntzel A.M. and Panarelli E.A., 2010. Influence of connectivity on Cladocera diversity in oxbow lakes in the Taquari River floodplain (MS, Brazil). Acta Limnol. Bras., 22, 93-101.

Gurney R., 1907. Further notes on Indian freshwater Entomostraca. Rec. Indian Mus., 1, 21-33.

Gurney R., 1916. On some fresh-water Entomostraca from Ceylon. Rec. Indian Mus., 1, 333-343.

Hanazato T., 1992. Direct and indirect effects of low-oxygen layers on lake zooplankton communities. Ergeb. Limnol., 35, 87-98.

Hann B.J., 1995. Invertebrate associations with submersed aquatic plants in a prairie wetland. UFS (Delta Marsh) Ann. Rep. 30, 78-84.

Hart R.C., 1985. Seasonality of aquatic invertebrates in low latitude and southern hemisphere inland waters. Hydrobiologia, 125, 151-178.

Idris B.A.G., 1983. Freshwater Zooplankton of Malaysia (Crustacea: Cladocer), Penerbit University Pertanian Malaysia, Serdang, Selangor, Malaysia, 153 p.

Inpang R., 2008. Annual Changes of Zooplankton Communities of Different Size Fractions in Thale-Noi, Phatthalung Province. MSc. thesis. Prince of Songkla University ed., Hat Yat, $176 \mathrm{p}$.

Kerfoot W.C., DeMott W.R. and DeAngelis D.L., 1985. Interactions among cladocerans: food limitation and exploative competition. Arch. Hydrobiol. Beih. Ergeb. Limnol., 21, 431-451.

Kersting K. and Van Der Leeuw W., 1976. The use of the Coulter counter for measuring the feeding rates of Daphnia magna. Hydrobiologia, 49, 233-237. 
Korhola A., Olander H. and Blom T., 2000. Cladoceran and chironomid assemblages as quantitative indicators of water depth in subarctic Fennoscandian lakes. J. Paleolimnol., 24, 43-54.

Korovchinsky N.M., 2010. A taxonomic revision of Pseudosida szalayi Daday, 1898 (Crustacea: Cladocera: Sididae) over its Asian range, with focus on the northernmost populations first recorded from the Amur River basin (Far East of Russia). Zootaxa, 2345, 1-18.

Korovchinsky N.M., 2013. Cladocera (Crustacea: Branchiopoda) of South East Asia: history of explorations, taxon richness and notes on zoogeography. J. Limnol., 72(Suppl. 2), e7.

Kotov A.A., 2003. Separation of Leydigia louisi Jenkin, 1934 from L. leydigi (Schoedler, 1863) (Chydoridae, Anomopoda, Cladocera). Hydrobiologia, 490, 147-168.

Kotov A.A., Maiphae S. and Sanoamuang L., 2005. Revision of Macrothrix paulensis-like species (Anomopoda, Cladocera, Branchiopoda) in Asia, and phylogeny of the paulensis group. Arch. Hydrobiol. Suppl. Monogr. Stud., 151, 269-299.

Leingpornpan S. and Leingporpan S., 2005. A study on aquatic plants and their distribution mapping in Thale-Noi Lake. Thaksin J., 8, 24-43.

Maiphae S., 2005. Taxonomy and Biogeography of the Cladocera from Southern Thailand, with Specific Reference to Alona Baird, 1843 and Macrothrix Baird, 1843. $\mathrm{PhD}$ thesis, Prince of Songkla University ed., Hat Yai, $314 \mathrm{p}$.

Maiphae S., 2008. Study of Cladocera in Thailand and trends in future. KKU Sci. J., 36, 171-181 (in Thai).

Melack J.M. and Kilham P., 1974. Photosynthetic rates of phytoplankton in East African alkaline, saline lakes. Limnol. Oceanogr., 19, 743-755.

Michaud J.P., 1991. A Citizen's Guide to Understanding and Monitoring Lakes and Streams, Vol. 360, Washington State Dept. of Ecology, Publications Office, Olympia, WA, USA, Publ. p. 94-149, 407-7472.

Moore G.M., 1939. A limnological investigation of the microscopic benthic fauna of Douglas Lake, Michigan. Ecol. Monogr., 9, 537-582.

Mourelatos S. and Lacroix G., 1990. In situ filtering rates of Cladocera: effect of body length, temperature, and food concentration. Limnol. Oceanogr., 35, 1101-1111.

Nachai S., 2006. Species diversity and distribution of Cladocera in Songkhram river basin. MSc thesis, Khon Kaen University ed., Khon Kaen, 87 p. (in Thai).

Nevalainen L., 2012. Distribution of benthic microcrustaceans along a water depth gradient in an Austrian Alpine lake Sedimentary evidence for niche separation. Limnologica, 42, 65-71.

Örnólfsdóttir E.B. and Einarsson A., 2004. Spatial and temporal variation of benthic Cladocera (Crustacea) studiedwith activity traps in Lake Myvatn, Iceland. Aquatic Ecol., 38, 239-251.

Paterson M., 1993. The distribution of microcrustacea in the littoral zone of a freshwater lake. Hydrobiologia, 263, 173-183.

Pholpunthin P., 1997. Freshwater zooplankton (Rotifera, Cladocera and Copepoda) from Thale-noi, South Thailand. J. Sci. Soc. Thailand, 23, 23-34.

Pholpunthin P., Maiphae S., Sriwoon R., Sa-ardrit P and Phuripong M., 2009. Plankton in Songkhla Lake Basin, i-designs, Songkhla, 89 p. (in Thai).
Ruensirikul J., Angsupanich S. and Phongdara A., 2007. Abundance and diversity of amphipod crustaceans in the Upper Songkhla Lagoon. Songklanakarin J. Sci. Technol., 29, 1225-1249 (in Thai).

Sa-ardrit P., 2002. Diversity and distribution of freshwater Cladocera in Trang province. MSc thesis. Prince of Songkhla University ed., Hat Yai, 98 p.

Saeng-aroon C. and Sanoamuang L., 2002. Species diversity and abundance of Cladocera in Lake Kud-Thing, Nong Khai Province. KKU Res. J., 7, 14-21 (in Thai).

Sinev A.Y., 2012. Alona kotovi sp. nov., a new species of Aloninae (Cladocera: Anomopoda: Chydoridae) from South Vietnam. Zootaxa, 3475, 45-54.

Sinev A.Y., 2014. A new and a rare species of Chydorus Leach, 1816 (Branchiopoda: Cladocera: Anomopoda) from Cat Tien National Park, Vietnam. Zootaxa, 3861, 127-144.

Sinev A.Y. and Kotov A.A., 2012. New and rare Aloninae (Cladocera: Anomopoda: Chydoridae) from Indochina. Zootaxa, 3334, 1-28.

Sinev A.Y., Garibian P.G. and Gu Y., 2016. A new species of Pseudochydorus Fryer, 1968 (Cladocera: Anomopoda: Chydoridae) from South-East Asia. Zootaxa, 4079, 119-128.

Smirnov N.N., 1974. Chydoridae of the world fauna. Fauna SSSR. Rakoobraznye, 1, 1-531.

Smirnov N.N., 1996. Cladocera: the Chydorinae and Sayciinae (Chydoridae) of the World. Guides to the Identification of the Microinvertebrates of the Continental Waters of the World, SPB Acad. Publ., Amsterdam, 197 p.

Stansfield J.H., Perrow M.R., Tench L.D., Jowitt A.J.D. and Taylor A.A.L., 1997. Submerged macrophytes as refuges for graz-ing Cladocera against fish predation: observations on seasonal changes in relation to macrophyte cover and predation pressure. Hydrobiologia, 342, 229-240.

Talling J.F. and Lemoalle J., 1998. Ecological Dynamics of Tropical Inland Waters, Cambridge University Press, London.

Tremel B., Frey S.E., Yan N.D., Somers K.M. and Pawson T.W., 2000. Habitat specificity of littoral Chydoridae (Crustacea, Branchiopoda, Anomopoda) in Plastic Lake, Ontario, Canada. Hydrobiologia, 432, 195-205.

Twombly S., 1983. Seasonal and short term fluctuation in zooplankton abundance in tropical Lake Malawi. Limnol. Oceanogr., 28, 1214-1224.

Van Damme K. and Dumont H.J., 2007. Limb morphology of the carnivorous anomopods Anchistropus emarginatus Sars, 1862 and Pseudochydorus globosus (Baird, 1843) (Crustacea: Branchiopoda: Anomopoda). Ann. Limnol. - Int. J. Lim., 43, 271-284.

Van Damme K. and Maiphae S., 2013. Salinalona gen. nov., an euryhaline chydorid lineage (Crustacea: Branchiopoda: Cladocera: Anomopoda) from the Oriental region. $J$. Limnol., 72(Suppl. 2), e9.

Van Damme K., Kotov A.A. and Dumont H.J., 2010. A checklist of names in Alona Baird 1843 (Crustacea: Cladocera: Chydoridae) and their current status: an analysis of the taxonomy of a lump genus. Zootaxa, 2330, 1-63.

Van Damme K., Sinev A.Y. and Dumont H.J., 2011. Separation of Anthalona gen.n. from Alona Baird, 1843 (Branchiopoda: Cladocera:Anomopoda): morphology and evolution of scraping stenothermic alonines. Zootaxa, 2875, 1-64.

Van Damme K., Maiphae S. and Sa-ardrit P., 2013. Inland swamps in South East Asia harbour hidden cladoceran 
diversities: species richness and the description of new paludal Chydoridae (Crustacea: Branchiopoda: Cladocera) from Southern Thailand. J. Limnol., 72(Suppl. 2), e10.

Vanni M., 1986. Competition in zooplankton communities: suppression of small species by Daphnia pulex. Limnol. Oceanogr., 31, 1039-1056.

Vijverberg J., 1980. Effect of temperature on laboratory studies on development and growth of Cladocera and Copepoda from Tjeukemeer, The Netherlands. Freshw. Biol., 10, 317-340.

Walseng B., Yan N.D., Pawson T.W. and Skarpaas O., 2008. Acidity versus habitat structure as regulators of littoral microcrustacean assemblages. Freshw. Biol., 53, 290-303.

Weber A.K. and Pirow R., 2009. Physiological responses of Daphnia pulex to acid stress. BMC Physiol., 9, 9.
Whiteside M.C., 1974. Chydorid (Cladocera) ecology: seasonal patterns and abundance of populations in Elk Lake, Minnesota. Ecology, 55, 538-550.

Whiteside M.C. and Harmsworth R., 1967. Species diversity in Chydorid (Cladocera) communities. Ecology, 48, 664-667.

Whiteside M.C. and Williams J.B., 1975. A new sampling technique for aquatic ecologists. Verh. Internat. Verein Limnol., 19, 1534-1539.

Whiteside M.C., Williams J.B. and White C.P., 1978. Seasonal abundance and pattern of chydorid Cladocera in mud and vegetative habitats. Ecology, 59, 1177-1188.

Wright D. and Shapiro J., 1990. Refuge availability: a key to understanding the summerdisappearance of Daphnia. Freshw. Biol., 24, 43-62. 